\author{
UNITED STATES DEPARTMENT OF THE INTERIOR \\ U.S. GEOLOGICAL SURVEY
}

\title{
MAP SHOWING MINERAL RESOURCE POTENTIAL OF THE LIVENGOOD QUADRANGLE, ALASKA
}

\author{
By
}

Richard B. McCammon', Thomas D. Light ${ }^{2}$, C. Dean Rinehart ${ }^{3}$, Florence R. Weber, Gregory K. Lee', and Scott W. Bie ${ }^{2}$

\section{Open-File Report 97-484-B}

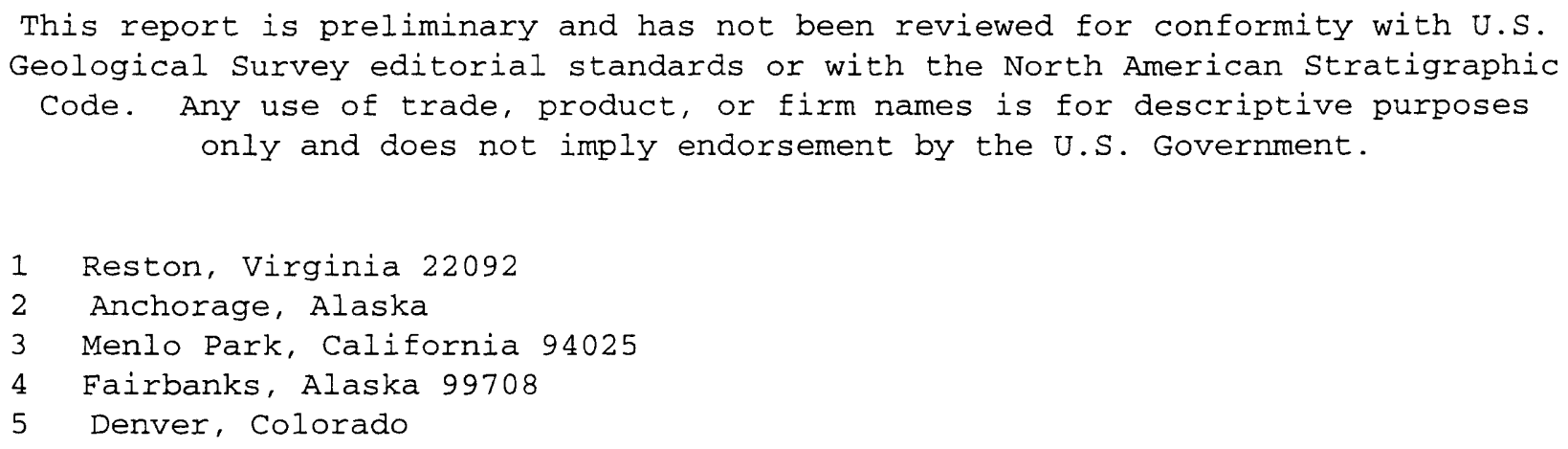




\title{
MAP SHOWING AREAS OF MINERAL RESOURCE POTENTIAL IN THE LIVENGOOD QUADRANGLE, ALASKA
}

\author{
By \\ Richard B. McCammon, Thomas D. Light, C. Dean Rinehart, Florence R. Weber, \\ Gregory K. Lee, and Scott W. Bie
}

1997

\section{INTRODUCTION}

This report, as part of the Alaska Mineral Resource Assessment Program (AMRAP), assesses the undiscovered mineral resources of the Livengood $1^{\circ}$ by $3^{\circ}$ quadrangle, Alaska, on the basis of deposit types judged to be permissive with respect to the available geologic, geochemical, geophysical, and mineral-resource data. The method of assessment used is similar to that described by Singer and Ovenshine (1979) and Singer (1993).

On the map, tracts are delineated that are permissive for the occurrence of one or more of the deposit types described in Cox and Singer (1986), Bliss (1992), and Hollister (1992). In some instances, tracts have been delineated for which it has not been possible to assign deposit types. In addition, stream drainages that contain detectable gold in stream-sediment and heavy-mineral concentrate samples are shown. Mines, prospects, and mineral occurrences in the quadrangle are shown and are described in Table 1 by location, mode of occurrence, commodities, and the record numbers in the Mineral Resource Data System (MRDS) and the Minerals Availability System (MAS). The description and the criteria used to delineate each permissive tract are listed in table 2. In a separate section of the report, estimates are given by deposit type of the number of undiscovered deposits at the 90th, the 50th, the 10th, the 5th, and the 1st percent 
confidence level. The maximum depth of consideration for the occurrence of undiscovered deposits for the quadrangle is defined as $1 \mathrm{~km}$ from the surface.

\section{SUMMARY OF GEOLOGY}

The Livengood quadrangle lies within the western part of the Yukon-Tanana Upland as defined by Wahrhaftig (1965). It is underlain by a northeastward trending sequence of Precambrian to Tertiary sedimentary, metasedimentary, and lesser volcanic and metavolcanic rocks metamorphosed mainly to greenschist facies, and intruded by widely scattered granitoid plutons of Cretaceous and Tertiary ages that form prominent topographic features. The major faults in the area are strike-slip splays of the Tintina fault zone, and northwest-verging thrust faults. The southeastern part of the quadrangle is underlain by crystalline rocks of the Yukon-Tanana metamorphic complex; the oldest rocks in the complex are crystalline schists. The metamorphic rocks range from greenschist and epidote-amphibolite facies to garnet-amphibolite facies (Robinson and others, 1990). The metamorphic grade generally decreases toward the northwest across the quadrangle. Scattered throughout the central and southern parts of the quadrangle are Cretaceous and Tertiary granitoid plutons.

Precambrian-Cambrian argillites, Ordovician mafic volcanic rocks, Silurian to Devonian limestone, and Mississippian(?) quartzite form the White Mountains, a highly faulted and folded block in the central part of the quadrangle. Mesozoic basinal deposits, north and west of the White Mountains, extend southwestward across the quadrangle and consist of conglomerate, sandstone, siltstone, and shale. North of the basinal deposits is a belt of grit, slate, mafic-ultramafic rocks, dolomite, chert, conglomerate, shale, and limestone of Precambrian to Triassic age. In the western part of the quadrangle, a major structural feature is displayed in a Mesozoic sequence that is folded around a core of 
Paleozoic and Precambrian sedimentary and volcanic rocks. The northwestern third of the quadrangle is underlain by mafic volcanic and intrusive rock and related chert and clastic sedimentary rocks of Mississippian to Triassic age. Gravel, sand, and silt of Holocene to Early Tertiary age blanket most of the area in the quadrangle.

\section{MINERAL RESOURCES}

Parts of six mining districts occur in the Livengood quadrangle (Ransome and Kerns, 1954) although only three of the districts contain significant identified mineral resources in the quadrangle (see fig. 1). The three major areas of identified resources in the Livengood quadrangle include the area around Sawtooth Mountain in the Rampart district, the area around the town of Livengood in the Tolovana district, and the area around Cleary Summit in the Fairbanks district. In the past, precious-metal and to a lesser extent base-metal lode deposits have yielded moderate amounts of gold and lesser amounts of silver, tungsten, and antimony ores. More important has been the gold production from placer deposits. Bottge (1986) shows a total of 180 claims in the Livengood quadrangle of which 72 are lode claims and 108 are placer claims. Perhaps the most significant recent discovery in this part of Alaska is the Fort Knox gold deposit located in the Fairbanks district $1 \mathrm{~km}$ to the south of the Livengood quadrangle. The deposit consists of scattered, thin, auriferous quartz veins in altered granodiorite to quartz monzonite along east-northeast-trending mineralized zones (Robinson and others, 1990; Hollister, 1991a, 1991b). Preliminary estimates indicate that the deposit may be the largest gold-bearing mineralized systems yet found in the Fairbanks district with a size approaching or larger than the total placer gold produced in the Fairbanks district. 


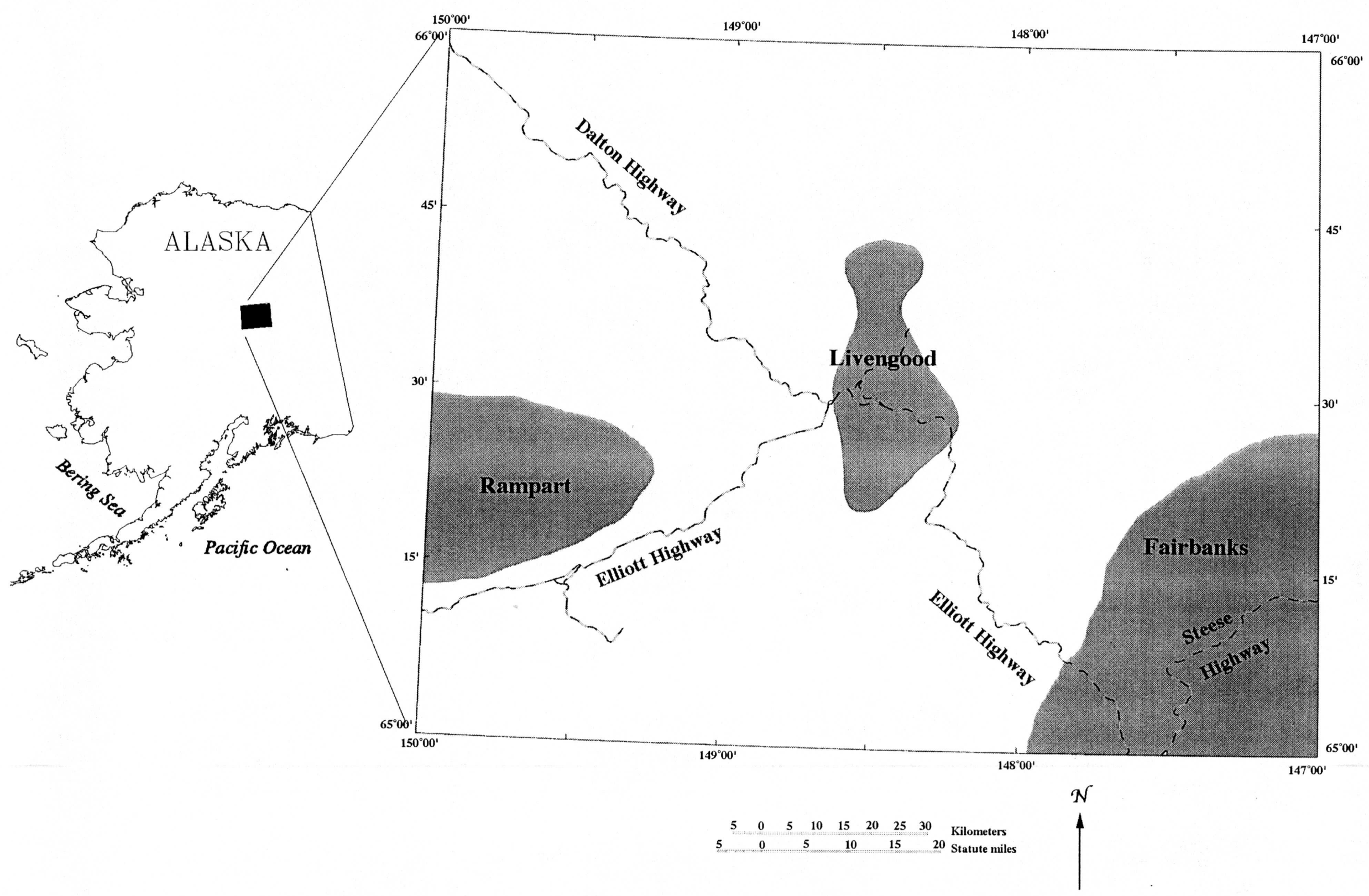

Fig. 1. Index map showing location of the Livengood quadrangle, Alaska, mining districts (shaded), and roads. 
Table 1. Selected identified metallic resources and mineralized occurrences

\begin{tabular}{|c|c|c|c|c|c|c|c|c|c|}
\hline & & Latitude & Longitude & & & MRDS & & & \\
\hline MapNo. & Name & Deg-Min-Sec & Deg-Min-Sec & DepositType & Commodities & No. & MAS No. & Comments & References \\
\hline 1 & Coffee Dome & $65-05-45$ & $147-06-25$ & $\begin{array}{l}\text { qtz-sulfide } \\
\text { veins }\end{array}$ & $\mathrm{Au}, \mathrm{Ag}, \mathrm{Pb}$ & $A 015468$ & 20490056 & Gold producer & Bottge,1986; Cobb, 1976 \\
\hline 2 & Kokomo Creek & $65-06-42$ & $147-08-25$ & placer & $\mathrm{Au}, \mathrm{Ag}$ & A015516 & 20490092 & Gold producer & Bottge,1986; Cobb, 1976 \\
\hline 3 & Alder Creek & $65-04-15$ & $147-11-20$ & placer & $\mathrm{Au}, \mathrm{Ag}$ & $A 015511$ & 20490091 & Gold producer & Bottge,1986; Cobb, 1976 \\
\hline 4 & Fish Creek & $65-00-28$ & $147-15-50$ & placer & $\begin{array}{l}\mathrm{Au}, \mathrm{Ag}, \mathrm{Sb}, \mathrm{Bi} \\
\mathrm{Sn}, \mathrm{W}\end{array}$ & $A 015510$ & 20490090 & $\begin{array}{l}\text { Gold, stibnite, Au- } \\
\text { bearing } \\
\text { bismuthinite. }\end{array}$ & Bottge,1986; Cobb, 1976 \\
\hline 5 & $\mathrm{Hi}-\mathrm{Yu}$ & $65-04-30$ & $147-16-35$ & qtz veins & $\begin{array}{l}\mathrm{Au}, \mathrm{Ag}, \mathrm{Sb}, \mathrm{Pb}, \\
\mathrm{Zn}\end{array}$ & A010677 & 20490051 & $\begin{array}{l}\text { Second-largest } \\
\text { lode-gold producer } \\
\text { in district }\end{array}$ & Bottge,1986; Cobb, 1976 \\
\hline 6 & Moose Creek & $65-04-45$ & $147-16-45$ & placer & $\mathrm{Au}, \mathrm{Ag}$ & & 20490159 & Gold producer & Bottge,1986; Cobb, 1976 \\
\hline 7 & Fairbanks Creek & $65-03-55$ & $147-18-30$ & placer & $\begin{array}{l}\mathrm{Au}, \mathrm{Ag}, \mathrm{Sb}, \mathrm{Sn}, \\
\mathrm{W}\end{array}$ & $A 015514$ & 20490050 & Gold producer & Bottge, 1986; Cobb, 1976 \\
\hline 8 & Gilmore & $65-04-03$ & $147-18-55$ & $q t z$ vein & $\mathrm{Au}, \mathrm{Ag}, \mathrm{Sb}$ & A001791 & 20490048 & Gold producer & Bottge,1986; Cobb, 1976 \\
\hline 9 & $\begin{array}{l}\text { McCarty - Henry } \\
\text { Ford }\end{array}$ & $65-03-45$ & $147-21-00$ & qtz veins & $\mathrm{Au}, \mathrm{Ag}, \mathrm{Sb}, \mathrm{Zn}$ & A015451 & 20490046 & $\begin{array}{l}\text { Gold, stibnite, } \\
\text { jamesonite, } \\
\text { sphalerite; mined } \\
1911-1917,1927- \\
1942\end{array}$ & Bottge,1986; Cobb, 1976 \\
\hline 10 & Rainbow & $65-01-35$ & $147-22-40$ & qtz vein & $\begin{array}{l}\mathrm{Au}, \mathrm{Ag}, \mathrm{Pb}, \mathrm{W}, \\
\mathrm{Zn}\end{array}$ & A001860 & 20490137 & Gold producer & Bottge, 1986; Cobb, 1976 \\
\hline 11 & Jackson & $65-02-55$ & $147-22-50$ & qtz vein & $\mathrm{Au}, \mathrm{Ag}$ & A001818 & 20490036 & Gold producer & Bottge,1986; Cobb, 1976 \\
\hline 12 & Chatham & $65-03-53$ & $147-22-50$ & qtz veins & $\mathrm{Au}, \mathrm{Ag}, \mathrm{Sb}$ & $\mathrm{A} 015444$ & 20490044 & Gold producer & Bottge,1986; Cobb, 1976 \\
\hline 13 & $\begin{array}{l}\text { Alaska (Jupiter- } \\
\text { Mars) }\end{array}$ & $65-04-10$ & $147-24-00$ & qtz vein & $\mathrm{Au}, \mathrm{Ag}$ & $\mathrm{A} 015437$ & 20490042 & Gold producer & Bottge,1986; Cobb, 1976 \\
\hline 14 & Chatham Creek & $65-04-25$ & $147-25-25$ & placer & $\begin{array}{l}\mathrm{Au}, \mathrm{Ag}, \mathrm{Sb}, \mathrm{Sn}, \\
W\end{array}$ & A015504 & 20490140 & Gold producer & Bottge,1986; Cobb, 1976 \\
\hline \multirow[t]{2}{*}{15} & Bedrock Creek & $65-07-05$ & $147-26-00$ & placer & $A u, A g, S n, W$ & A015502 & 20490163 & Gold producer & Bottge,1986; Cobb, 1976 \\
\hline & $\begin{array}{l}\text { Wackwitz (Cleary } \\
\text { Summit) }\end{array}$ & $65-02-50$ & $147-26-00$ & $\begin{array}{l}\text { qtz-sulfide } \\
\text { veins }\end{array}$ & $\mathrm{Au}, \mathrm{Sb}, \mathrm{Pb}$ & $A 015398$ & 20490035 & Antimony producer & Bottge,1986; Cobb, 1976 \\
\hline
\end{tabular}


Table 1 (continued). Selected identified metallic resources and mineralized occurrences

\begin{tabular}{|c|c|c|c|c|c|c|c|c|c|}
\hline MapNo. & Name & $\begin{array}{l}\text { Latıtude } \\
\text { Deg-Min- }\end{array}$ & $\begin{array}{c}\text { Longitude } \\
\text { Deg-Min-Sec }\end{array}$ & DepositType & Commodities & MRDS No. & MAS No. & Comments & References \\
\hline 16 & Cleary Hill & $65-04-15$ & $147-26-05$ & $\begin{array}{l}\text { qtz- and qtz- } \\
\text { sulfide veins }\end{array}$ & $\begin{array}{l}\mathrm{Au}, \mathrm{Ag}, \mathrm{Sb} \\
\mathrm{Cu}, \mathrm{Pb}, \mathrm{Sn} \\
\mathrm{W}, \mathrm{Zn}\end{array}$ & $\mathrm{A} 015431$ & 20490039 & $\begin{array}{l}\text { Gold, stibnite, } \\
\text { cpy,galena, cassiterite, } \\
\text { sheelite, } \\
\text { sph,jamesonite; major } \\
\text { lode-gold producer in } \\
\text { district; mined 1909- } \\
\text { 1915, 1927, 1929-1942, } \\
1949\end{array}$ & Bottge, 1986; Cobb, 1976 \\
\hline 17 & Cleary Creek & $65-04-25$ & $147-26-30$ & placer & $\begin{array}{l}\mathrm{Au}, \mathrm{Ag}, \mathrm{Sb}, \\
\mathrm{Sn}, \mathrm{W}\end{array}$ & A015505 & 20490088 & Gold producer & Bottge,1986; Cobb, 1976 \\
\hline 18 & Twin Creek & $65-02-02$ & $147-27-00$ & placer & $\mathrm{Au}, \mathrm{Ag}, \mathrm{Sn}$ & A015509 & 20490157 & Gold producer & Bottge,1986; Cobb, 1976 \\
\hline 19 & $\begin{array}{l}\text { Herschberger, } \\
\text { Beall, and } \\
\text { Phipps }\end{array}$ & $65-03-45$ & $147-27-20$ & qtz vein & $\mathrm{Au}, \mathrm{Ag}$ & A015428 & 20490038 & Gold producer & Bottge, 1986; Cobb, 1976 \\
\hline 20 & Burnet Galena & $65-02-10$ & $147-28-15$ & $\begin{array}{l}\text { qtz-sulfide } \\
\text { veins }\end{array}$ & $\begin{array}{l}\mathrm{Au}, \mathrm{Ag}, \mathrm{Pb}, \\
\mathrm{Sb}\end{array}$ & $A 015379$ & 20490030 & Gold producer & Bottge,1986; Cobb, 1976 \\
\hline 21 & Mohawk & $65-02-50$ & $147-28-30$ & qtz veins & $\mathrm{Au}, \mathrm{Ag}, \mathrm{Sb}$ & $A 015374$ & 20490029 & Gold producer & Bottge,1986; Cobb, 1976 \\
\hline 22 & Chechako No. 1 & $65-03-25$ & $147-28-30$ & $\begin{array}{l}\text { qtz- and qtz- } \\
\text { sulfide veins }\end{array}$ & $\begin{array}{l}\mathrm{Au}, \mathrm{Ag}, \mathrm{Sb} \\
\mathrm{Cu}, \mathrm{Pb}, \mathrm{Zn}\end{array}$ & A015422 & 20490037 & Gold producer & Bottge,1986; Cobb, 1976 \\
\hline 23 & Pedro Creek & $65-00-20$ & $147-30-35$ & placer & $\mathrm{Au}, \mathrm{Ag}, \mathrm{Sn}$ & $A 015507$ & 20490089 & Gold producer & Bottge,1986; Cobb, 1976 \\
\hline 24 & $\begin{array}{l}\text { Little Eldorado } \\
\text { Creek }\end{array}$ & $65-03-35$ & $147-31-55$ & placer & $\begin{array}{l}\mathrm{Au}, \mathrm{Ag}, \mathrm{Sn}, \\
W\end{array}$ & $A 015501$ & 20490087 & Gold producer & Bottge,1986; Cobb, 1976 \\
\hline 25 & Soo & $65-02-10$ & $147-32-40$ & $\begin{array}{l}\text { qtz- and qtz- } \\
\text { sulfide veins }\end{array}$ & $\begin{array}{l}\mathrm{Au}, \mathrm{Ag}, \mathrm{Sb} \\
\mathrm{Pb}, \mathrm{Cu} ?\end{array}$ & A015418 & 20490023 & Gold producer & Bottge,1986; Cobb, 1976 \\
\hline 26 & Silver Fox & $65-00-36$ & $147-34-10$ & qtz-veins & $\begin{array}{l}\mathrm{Mo}, \mathrm{Cu}, \mathrm{Ag} \\
\mathrm{Pb}, \mathrm{Zn} \mathrm{Au} ?\end{array}$ & A015414 & 20490020 & $\begin{array}{l}\text { Molybdenite-qtz veins in } \\
\text { granodiorite; py and cpy } \\
\text { in fractures }\end{array}$ & Mowatt, 1974 \\
\hline 27 & Old Glory (Ohio) & $65-01-08$ & $147-34-36$ & $\begin{array}{l}\text { contact- } \\
\text { metamorphic }\end{array}$ & W & A015412 & 20490018 & $\begin{array}{l}\text { Finely disseminated } \\
\text { scheelite in qtz-mica } \\
\text { schist }\end{array}$ & Bottge,1986; Cobb, 1976 \\
\hline 28 & Fox Creek & $65-00-04$ & $147-36-35$ & placer & $\mathrm{Au}, \mathrm{Ag}$ & & 20490079 & Gold producer & Bottge, 1986; Cobb, 1976 \\
\hline 29 & Dome Creek & $65-03-10$ & $147-38-45$ & placer & $\begin{array}{l}\mathrm{Au}, \mathrm{Ag}, \mathrm{Sn}, \\
\mathrm{W}\end{array}$ & A015499 & 20490085 & Gold producer & Bottge,1986; Cobb, 1976 \\
\hline 30 & Vault Creek & $65-02-45$ & $147-43-10$ & placer & $\mathrm{Au}, \mathrm{Ag}$ & A015496 & 20490080 & Gold producer & Bottge,1986; Cobb, 1976 \\
\hline
\end{tabular}


Table 1 (continued). Selected identified metallic resources and mineralized occurrences

\begin{tabular}{|c|c|c|c|c|c|c|c|c|c|}
\hline MapNo. & Name & $\begin{array}{l}\text { Latıtude } \\
\text { Deg-Min- }\end{array}$ & $\begin{array}{l}\text { Longıtude } \\
\text { Deg-Min-Sec }\end{array}$ & DepositType & Commodities & MRDS No. & MAS No. & Comments & References \\
\hline 31 & Scrafford & $65-00-13$ & $147-44-25$ & $\begin{array}{l}\text { qtz-sulfide } \\
\text { veins }\end{array}$ & $\begin{array}{l}\mathrm{Sb}, \mathrm{Au}, \mathrm{Pb} \\
\mathrm{Ag}\end{array}$ & $A 001867$ & 20490009 & $\begin{array}{l}\text { Second-largest } \\
\text { producer of antimony in } \\
\text { Alaska; est. prod. } 2,300 \\
\text { mt antimony }\end{array}$ & $\begin{array}{l}\text { Robinson and Bundtzen, } \\
1982\end{array}$ \\
\hline 32 & Our Creek & $65-01-20$ & $147-52-10$ & placer & $\mathrm{Au}, \mathrm{Ag}$ & A015494 & 20490078 & Gold producer & Bottge,1986; Cobb, 1976 \\
\hline 33 & Nome Creek & $65-21-52$ & $147-30-10$ & placer & $\mathrm{Au}, \mathrm{Ag}$ & A015517 & 20490093 & Gold producer & Bottge, 1986; Cobb, 1976 \\
\hline 34 & $\begin{array}{l}\text { Mount Prindle } \\
\text { (Roy Creek) }\end{array}$ & $65-29-06$ & $147-04-31$ & vein & Th, REE, U & No record & 20500251 & $\begin{array}{l}\text { Th-REE-bearing veins in } \\
\text { syenite complex; }>2000 \\
\text { Th, >1000 La, >2000 } \\
\text { Sc, }>2000 \mathrm{Y}\end{array}$ & Burton, 1981 \\
\hline 35 & Cache Mountain & $65-29-09$ & $147-18-48$ & outcrop & $\mathrm{Sn}$ & No record & 20490148 & $\begin{array}{l}\text { Qtz-chlorite altered } \\
\text { porphyritic granite }\end{array}$ & $\begin{array}{l}\text { Dean Warner, } 1984 \text {, } \\
\text { written communication }\end{array}$ \\
\hline 36 & Wilber Creek & $65-27-28$ & $148-21-40$ & placer & $\mathrm{Au}, \mathrm{Ag}$ & A015492 & 20490075 & Gold producer & Bottge,1986; Cobb, 1976 \\
\hline 37 & Steel Creek & $65-27-42$ & $148-25-25$ & placer & $\mathrm{Au}, \mathrm{Ag}, \mathrm{W}$ & $A 015491$ & 20490074 & Gold producer & Bottge,1986; Cobb, 1976 \\
\hline 38 & $\begin{array}{l}\text { Amy Creek- } \\
\text { Fanny Gulch }\end{array}$ & $65-32-40$ & $148-25-50$ & placer & $\mathrm{Au}, \mathrm{Ag}$ & A015487 & 20490069 & Gold producer & Bottge,1986; Cobb, 1976 \\
\hline 39 & Ester Creek & $65-30-05$ & $148-27-40$ & placer & $\mathrm{Au}, \mathrm{Ag}, \mathrm{Hg}$ & A015490 & 20490073 & Gold producer & Bottge,1986; Cobb, 1976 \\
\hline 40 & Franklin Creek & $65-33-04$ & $148-30-05$ & placer & $\mathrm{Au}, \mathrm{Ag}$ & $A 015479$ & 20490098 & Gold producer & Bottge,1986; Cobb, 1976 \\
\hline 41 & $\begin{array}{l}\text { Old Smoky } \\
\text { Prospect }\end{array}$ & $65-30-18$ & $148-30-54$ & vein & $\mathrm{Au}, \mathrm{Sb}$ & A015402 & 20490004 & $\begin{array}{l}\text { Gold-antimony } \\
\text { mineralization in altered } \\
\text { felsic dikes }\end{array}$ & Allegro, 1984 \\
\hline 42 & Amy Creek & $65-32-40$ & $148-25-50$ & placer & $\begin{array}{l}\mathrm{Au}, \mathrm{Ag}, \mathrm{Sb}, \\
\mathrm{Cr}\end{array}$ & $A 015487$ & 20490069 & Gold producer & Bottge,1986; Cobb, 1976 \\
\hline 43 & Gertrude Creek & $65-31-48$ & $148-29-10$ & placer & $\mathrm{Au}, \mathrm{Ag}$ & A015493 & 20490067 & Gold producer & Bottge,1986; Cobb, 1976 \\
\hline 44 & Olive Creek & $65-29-34$ & $148-30-10$ & placer & $\begin{array}{l}\mathrm{Au}, \mathrm{Ag}, \mathrm{Cr} \\
\mathrm{Hg}, \mathrm{W}\end{array}$ & A015489 & 20490072 & Gold producer & Bottge,1986; Cobb, 1976 \\
\hline 45 & Ruth Creek & $65-31-08$ & $148-32-05$ & placer & $\begin{array}{l}\mathrm{Au}, \mathrm{Ag}, \mathrm{Sb} \\
\mathrm{Cr}, \mathrm{Hg}, \mathrm{W}\end{array}$ & $A 015483$ & 20490065 & Gold producer & Bottge, 1986; Cobb, 1976 \\
\hline 46 & Livengood Creek & $65-31-30$ & $148-33-00$ & placer & $\begin{array}{l}\mathrm{Au}, \mathrm{Ag}, \mathrm{Sb} \\
\mathrm{Cr}, \mathrm{Hg}, \mathrm{Sn}, \\
\text { W }\end{array}$ & A015480 & 20490064 & $\begin{array}{l}\text { Published reserves- } \\
\text { resources } 370,000 \mathrm{oz} \\
\mathrm{Au}\end{array}$ & Hargreaves, 1975 \\
\hline 47 & Lillian Creek & $65-30-36$ & $148-33-00$ & placer & $\begin{array}{l}\mathrm{Au}, \mathrm{Ag}, \mathrm{Sb} \\
\mathrm{Cr}, \mathrm{Hg}, \mathrm{W}\end{array}$ & A015484 & 20490066 & Gold producer & Bottge,1986; Cobb, 1976 \\
\hline 48 & Myrtle Creek & $65-32-07$ & $148-34-00$ & placer & $\mathrm{Au}, \mathrm{Ag}$ & A015482 & 20490099 & Gold producer & Bottge,1986; Cobb, 1976 \\
\hline
\end{tabular}


Table 1 (continued). Selected identified metallic resources and mineralized occurrences

\begin{tabular}{|c|c|c|c|c|c|c|c|c|c|}
\hline MapNo. & Name & $\begin{array}{l}\text { Latitude } \\
\text { Deg-Min- }\end{array}$ & $\begin{array}{c}\text { Longitude } \\
\text { Deg-Min-Sec }\end{array}$ & DepositType & Commodities & MRDS No. & MAS No. & Comments & References \\
\hline 48 & $\begin{array}{l}\text { Sawtooth } \\
\text { Mountain }\end{array}$ & $65-22-35$ & $149-31-25$ & stibnite-vein & $\mathrm{Sb}$ & $\mathrm{A} 015372$ & 20490002 & $\begin{array}{l}\text { Massive stibnite; est. } \\
\text { prod. } 590 \text { tonnes with } 58 \\
\text { pct. Sb2S3 }\end{array}$ & Bottge, 1986; Cobb, 1976 \\
\hline 49 & Huron Creek & $65-25-24$ & $149-28-38$ & veinlets & Mo & No record & No record & $\begin{array}{l}\text { Molybdenite-bearing qtz } \\
\text { veinlets in massive } \\
\text { porhyritic qtz monzonite }\end{array}$ & Light and Rinehart, 1989 \\
\hline 50 & Gunnison Creek & $65-03-50$ & $149-40-45$ & placer & $\mathrm{Au}, \mathrm{Ag}, \mathrm{W}$ & A015475 & 20490061 & Gold producer & Bottge, 1986 \\
\hline 51 & Quail Creek & $65-21-46$ & $149-50-45$ & placer, vein & $\begin{array}{l}\mathrm{Au}, \mathrm{Ag}, \mathrm{Hg}, \\
\mathrm{Sn}, \mathrm{W}\end{array}$ & $A 015473$ & 20490060 & Gold producer & Bottge, 1986 \\
\hline 52 & Idaho Bar & $65-27-04$ & $149-59-15$ & placer & $\mathrm{Au}, \mathrm{Ag}$ & $\mathrm{A} 015471$ & 20490058 & Gold producer & Bottge, 1986 \\
\hline 53 & Hunter Creek & $65-28-20$ & $149-59-25$ & placer & $\begin{array}{l}\mathrm{Cu}, \mathrm{Au}, \mathrm{Ag}, \\
\mathrm{Pb}, \mathrm{Hg}, \mathrm{Sn}\end{array}$ & $\mathrm{A} 015470$ & 20490057 & Gold producer & Bottge, 1986 \\
\hline 54 & Mount Schwatka & $65-53-27$ & $147-10-03$ & gossan, rubble & $\mathrm{Pb}, \mathrm{Zn}, \mathrm{Ag}$ & No record & 20490152 & $\begin{array}{l}\text { Secondary smithsonite } \\
\text { in gossan }\end{array}$ & Barker, 1978 \\
\hline
\end{tabular}


The assessment of the undiscovered mineral resources in the Livengood quadrangle includes ten deposit types, each of which is discussed below. A general description of each deposit type is given together with the evidence that was used to judge whether a tract was permissive (or favorable) for the occurrence of that deposit type within the tract. The order of presentation is based upon a combination of the relative economic importance and the likelihood of occurrence of the deposit types identified. For some of the tracts, favorableness as opposed to permissiveness is considered due to the spatial distribution of rock types associated with the occurrence or nonoccurrence of specific deposit types. As an aid to the reader, a figure showing the areal extent of each tract accompanies the description of each tract.

\section{PLUTONIC PORPHYRY GOLD DEPOSITS}

Plutonic porphyry gold deposits are characterized by felsic porphyry plutons containing disseminated gold and gold in quartz veins and stringers. The Fort Knox deposit, $1 \mathrm{~km}$ south of the Livengood quadrangle, is considered to be a new type of deposit (Hollister, 1991c; Hollister, 1992). The size of the Fort Knox deposit is reported to be 82 million metric tons with an average grade of $1.4 \mathrm{~g} / \mathrm{mt}$ of gold (Swainbank and others, 1991). Plutonic porphyry gold deposits are similar in many respects to porphyry copper or porphyry molybdenum deposits, except that plutonic porphyry gold deposits contain little or no economically recoverable copper or molybdenum (Hollister, 1991c).

The spatial association of gold in the Livengood quadrangle with granitic plutons was recognized early in the exploration for placer deposits (Mertie, 1937) and the spatial association of both plutons and faults with gold in the Livengood quadrangle has been discussed by Light and others (1993). Plutons similar in age and composition to the Fort Knox pluton occur within the Livengood quadrangle, and are considered 
permissive for the occurrence of undiscovered plutonic porphyry gold deposits. The two areas that are considered permissive for the occurrence of undiscovered plutonic porphyry gold deposits are in the vicinity of Livengood (tract 1 ) and in the vicinity of Pedro Dome (tract 2).

In the Livengood area (tract 1, figure 2), gold mineralization has been interpreted as being spatially related to quartz monzonite and monzonite intrusions by Foster (1968). However, a direct genetic relationship between the plutons and the gold is not well defined. Considering the amount of placer gold recovered from the Livengood area and the amount of gold remaining in identified resources, it is possible, nonetheless, to hypothesize a lode source of placer gold as would be contained in an undiscovered plutonic porphyry gold deposit. Additionally, based on gold samples with trace metal ratios similar to those near the plutons around the town of Livengood (John Cathrall, USGS, pers. comm.), the area between the South Fork of Hess Creek and McHugh Creek may contain a buried pluton.

Tract 2 (figure 3) consists of scattered exposures of plutonic rocks, the largest being granodiorite bodies at Pedro Dome which are elongate northeastward, parallel to the regional structural grain. The area contains small bodies of quartz-feldspar porphyritic granite that locally intrude the granodiorite. The granodiorite is fine to medium grained, massive, and fairly homogeneous. Radiometric ages of $90.7 \pm 5.1 \mathrm{Ma}$ (hornblende) have been reported (Blum, 1982) that are similar to the age (93 Ma) of the Ft. Knox pluton (Hollister, 1991b). The plutons in and around Pedro Dome are situated in a regional structure that is parallel to the structure that includes the Ft. Knox pluton. Regional structure is considered a major factor in the mineralization in the district and also in controlling emplacement of the plutons (Hollister, 1991b). 


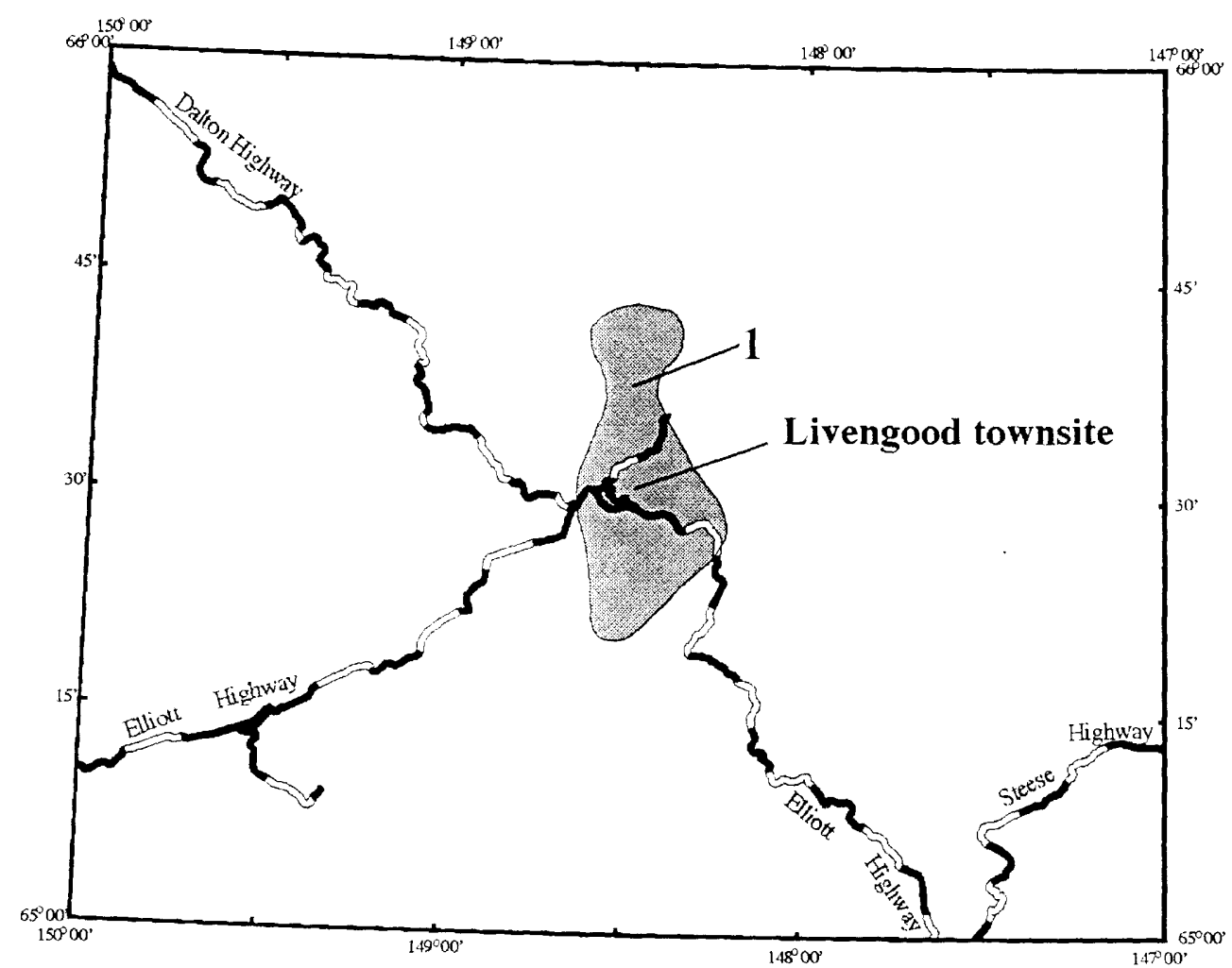

Figure 2. Area of mineral resource tract 1 (shaded).

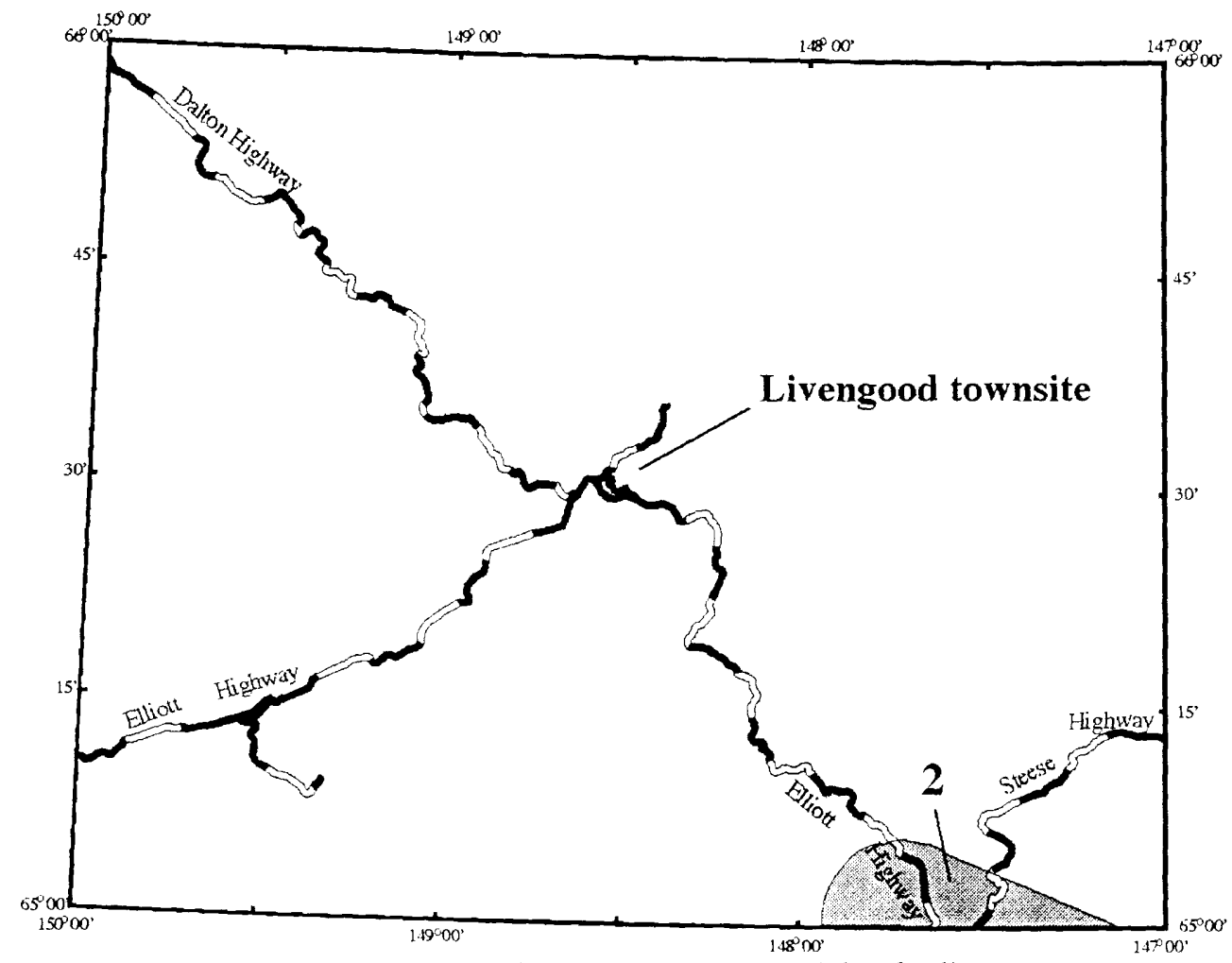

Figure 3. Area of mineral resource tract 2 (shaded). 


\section{PLACER GOLD DEPOSITS}

Placer gold deposits consist of elemental gold and platinum-group alloys in grains and rarely nuggets in gravel, sand, silt, and clay, and their consolidated equivalents, in alluvial, beach, eolian, and rarely glacial deposits (Yeend, 1986). Nearly all of the placer deposits in the Livengood quadrangle consist of buried bench gravels on old terraces or buried stream deposits derived from older bench gravels.

The total production of placer gold from the Livengood quadrangle is estimated to be 47.4 metric tons. This figure can be compared with the 1990 production of 0.13 metric tons of placer gold in the Livengood/Tolovana district (T.K. Bundtzen, oral comm.) and the 1990 production of 2.1 metric tons of placer gold in the state of Alaska (Swainbank and others, 1991).

Gold has been recovered from placer deposits in three principal areas in the Livengood quadrangle. These areas are the Fairbanks mining district in the southern and southeastern part of the quadrangle, the Tolovana district around the town of Livengood in the center of the quadrangle, and the northern Sawtooth Mountains (eastern Rampart district) in the western part of the quadrangle. Within these areas, gravel benches formed in ancestral stream drainages have been the major host for placer gold (Mertie, 1937). In addition, reworked placer gold in the present stream drainages has contributed to the overall gold production, and is the primary pathfinder for concealed bench deposits (Light and others, 1988).

Gold in the Fairbanks mining district was discovered by Felix Pedro on Pedro Creek in the Livengood quadrangle in 1902. The Fairbanks district comprises the southeastern quarter of the Livengood quadrangle and includes the drainage of the Chatanika River which has produced most of the placer gold in the district. Since the initial discovery, the Fairbanks district has produced an estimated 238 metric tons of gold. Of this total, 
only 7.3 metric tons have come from lode deposits (Robinson and others, 1990; Sherman, 1987). Of the total placer gold production, 35.1 metric tons have been produced from the Cleary Creek area within the Chatanika River drainage and lesser amounts from Fairbanks Creek and Nome Creek. Nome Creek has produced an estimated 0.9 metric tons (McCammon and others, 1988).

The source of placer gold in the Fairbanks mining district has been attributed to two sources. Intrusive granitic plutons of inferred Late Cretaceous age (93 Ma; Hollister, 1991b) like the Fort Knox pluton are postulated to have contributed large quantities of native gold from both disseminated gold and gold in quartz veins (Hollister, 1991a). An alternate source has been postulated by Robinson and others (1982) who described the Cleary subunit ( $\mathrm{Zfc})$, a 400 -foot thick sequence of felsic schist, quartzite, greenstone, and metavolcanic rocks in the Fairbanks schist unit. They have interpreted the Cleary sequence as the source of gold that has been subsequently remobilized by the plutons. It is likely some combination of the two processes have contributed to the quantities of gold recovered from the district.

In the Livengood mining district, gold was discovered in Livengood Creek by Jay Livengood and N.R. Hudson in 1914. Since the initial discovery, gold has also been recovered from the drainages of Amy Creek, Gertrude Creek, Lillian Creek, Lucky Creek, Myrtle Creek, Olive Creek, and Ruth Creek (Bailey and others, 1987). The bulk of the gold production has come from Livengood Creek (Herbert, 1991). Over the period 1914-1990, it is estimated that 14.6 metric tons of gold have been produced from the Livengood/Tolovana district (Bundtzen, Alaska Division of Geological and Geophysical Surveys, oral comm.). Published estimates indicate 2.9 metric tons of measured gold resources remain in places of Livengood Creek, 2.9 metric tons of indicated placer gold, and 5.7 metric tons of inferred placer gold (Hargreaves, 1975).

Placer gold at the Hunter Creek and Quail Creek deposits mark the eastern extent of the Rampart mining district. Gold was discovered in Hunter Creek by William Hunter 
in 1896, and was mined from gravel benches above the present drainage level (Mertie, 1934). Quail Creek drains the north side of Wolverine Mountain. Much of the gold in the Quail Creek drainage is in a bench on the north side of the creek (Mertie, 1934). The total production from the Rampart district is estimated to be 2.71 metric tons of gold. Of this total, 0.65 metric tons are estimated to have been produced from the Hunter-Dawson Creek area.

Tracts $3 a, 3 b$, and $3 c$ (figure 4 ) are the areas identified as permissive for undiscovered placer gold deposits. Stream drainages containing gold are depicted in bold on the accompanying map. These drainages contain gold in stream-sediment samples (Cathrall and others, 1985; Arbogast and others, 1991), or in other samples reported in the literature (Light and others, in press). Where gold-bearing drainages fall outside these tracts, they are considered to be isolated occurrences of limited extent that, based on the available data, are not judged to be indicative of significant undiscovered placer gold deposits. For example, gold in a concentrate sample north of the Yukon River, in the northwest corner of the quadrangle, may be derived from mafic units in the Rampart volcanics in either the Livengood quadrangle or Tanana quadrangle to the west. However, the lack of any evidence for granitic intrusions or structural conduits suggest that the geologic setting is unfavorable for lode gold concentrations to serve as source for placer gold deposits.

Tract 3a encompasses almost all the gold-bearing streams of the northern Fairbanks mining district in the southeastern Livengood quadrangle. Although this area has been extensively prospected and mined in the past, the tendency for placer deposits to be developed best at the base of Tertiary gravel terraces suggest that there may be additional deposits or addition pay zones in previously mined deposits (Balen, 1988; Fechner and Balen, 1988a, 1988b). However, such deposits, if they exist, are likely to be small in size. 
Tract $3 \mathrm{~b}$ encompasses the gold-bearing streams in the area about $30 \mathrm{~km}(20 \mathrm{mi})$ to the north and south of Livengood (Karl and others, 1988). The area has been thoroughly explored so that the probability of many new discoveries is low. The upper reaches of Hess Creek and Bear Creek however contain numerous gold-bearing samples and warrant further evaluation.

Tract $3 \mathrm{c}$ comprises the gold-bearing streams in the Sawtooth Mountains and its vicinity. Numerous streams draining the north flank of the Sawtooth Mountains contain gold in stream-sediment samples. The gold found in Hutlinana Creek and in upper Uncle Sam Creek may be related to low-sulfide gold quartz veins or disseminated gold in the metamorphic rocks in the area.

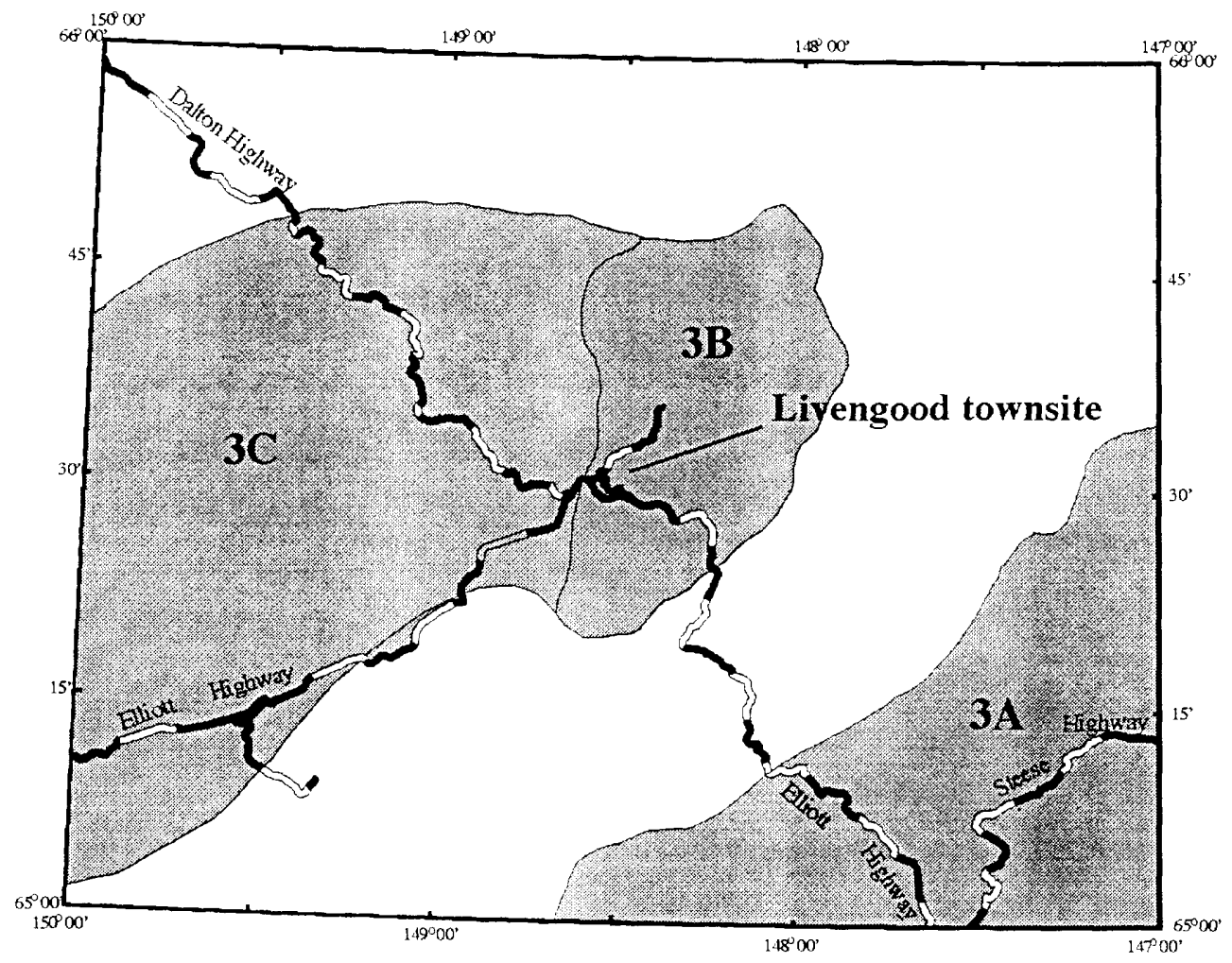

Figure 4. Area of mineral resource tracts $3 a, 3 b$, and $3 c$ (shaded). 


\section{LOW-SULFIDE GOLD-QUARTZ VEIN DEPOSITS}

Low-sulfide gold-quartz veins consist of gold in massive, persistent quartz veins mainly in regionally metamorphosed volcanic rocks, metamorphosed graywacke, chert, and shale (Berger, 1986). The veins in these deposits are generally post-metamorphic and locally cut granitic rocks. Associated minerals are minor pyrite, galena, sphalerite, chalcopyrite, arsenopyrite, and pyrrhotite. Alteration minerals include quartz, siderite, albite, and carbonate. Notable examples of this type of deposit occur in the Livengood quadrangle and include the Cleary Hill, Hi-Yu, McCarty-Henry Ford, and the Soo deposits in the Fairbanks district (Chapman and Foster, 1969). It has been estimated that these deposits and many smaller, similar deposits nearby that have produced gold intermittently, have accounted for 65 percent, or 7.26 million grams of gold, out of a total of 11.2 million grams of lode gold produced in the Fairbanks district (Sherman, 1987). These deposits consist of gold-sulfide-quartz, and gold-quartz veins and breccias hosted in faults, fractures, shear zones, and stockworks developed in the Cleary sequence and within Cretaceous and Tertiary intrusive complexes (Robinson and others, 1990). The deposits are usually podiform and discontinuous and contain highly varied precious-metal values. Tract $4 a$ (figure 5) is underlain principally by the Cleary sequence and is identified as being permissive for undiscovered low-sulfide gold quartz vein deposits. It is likely that undiscovered deposits, if they exist, will be small, with the upper limit being a few thousand to a few tens of thousands of tonnes of ore. Tract $4 \mathrm{~b}$ which surrounds tract $4 \mathrm{a}$ is underlain by crystalline rocks of the Yukon-Tanana metamorphic complex. Earlier studies by Cady and Weber (1983) determined that linear magnetic highs reflect magnetic chloritic schists within the Fairbanks Schists which were interpreted as belonging to the Cleary sequence. Such linear magnetic highs extend southwestward from Mount Prindle toward the heads of Trail and Ophir Creeks 
and are coincident with a known antiform. This, together with the known occurrence of placer gold in both Trail and Ophir Creeks, whose headwaters originate north of where the Cleary sequence crops out, suggested to Light and others, (1987) that the Cleary sequence may underlay part of tract $10 \mathrm{~b}$ (figure 11) which is therefore permissive for the occurrence of low-sulfide gold quartz veins.

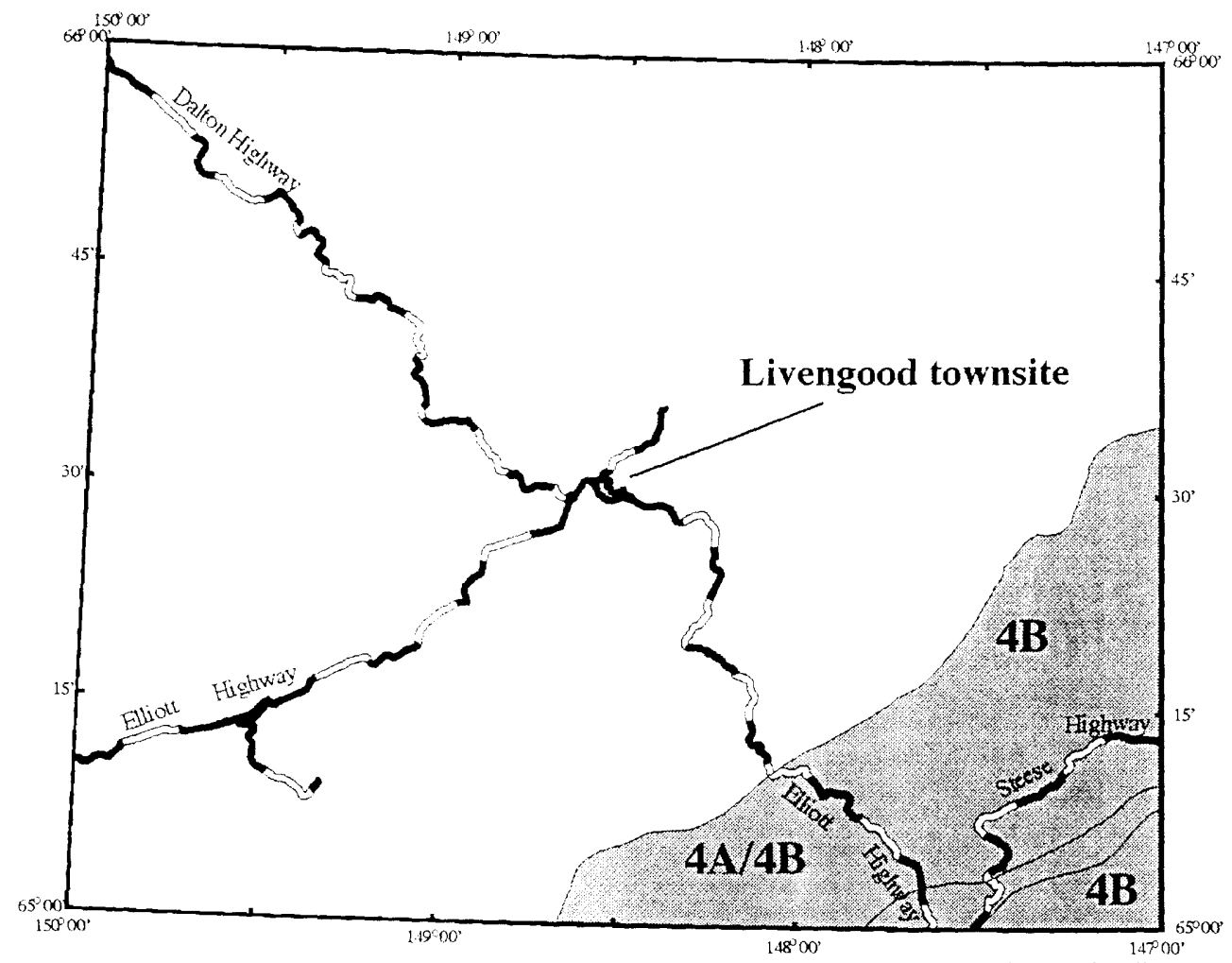

Figure 5. Area of mineral resource tracts $4 a$ and $4 b$ (shaded).

In the early 1900's, a group of lode gold claims was staked near the heads of Ruth, Lillian, and Olive Creeks, near Livengood townsite. The claims were located principally on quartz stringers up to $8 \mathrm{~cm}$ wide, containing pyrite, arsenopyrite, stibnite, and gold, that cut diverse rock types (Nokleberg and others, 1987). Two concentrate samples collected south of the town of Livengood near Amy Dome collectively contain gold, 
cinnabar, galena, sphalerite, and scheelite (Tripp, in press). Mineralogical data of concentrate samples collected in the area of Livengood Dome, Money Knob, and Amy Dome by Cathrall and others (1989) suggest that precious- and base-metal deposits occur in the area.

\section{POLYMETALLIC VEIN DEPOSITS}

Polymetallic vein deposits consist of narrow, subvertical structures such as fractures, shears, or faults which are filled, either partially or completely, with sulfide minerals and associated silicates, carbonates, or sulfates (Sangster, 1984; Cox, 1986). The veins are discordant where they occur in layered host rocks; in plutonic rocks, the veins appear to be later than all phases of intrusion. Regardless of their occurrence, the veins are considered to be related to felsic and intermediate hypabyssal intrusions in sedimentary and metamorphic terranes, or to metamorphic fluids formed during waning stages of regional metamorphism. The primary ore minerals are argentiferous galena, sphalerite, argentite, tetrahedrite, and pyrargyrite. Within the Livengood quadrangle, base-metal polymetallic veins are identified as being permissive in Tracts 1 and 5 (figure 2 and 6). Tract 1, in addition to being considered permissive for the occurrence of low-sulfide gold-quartz vein deposits (see above), is also considered permissive for the occurrence of polymetallic vein deposits for the following reasons: (1) presence of lode gold claims, (2) wide variety of sulfide minerals contained in heavy-mineral pan concentrate samples, and (3) presence of felsic porphyry dikes. The smallest pluton, the Huron Creek pluton, was described recently as having a potential for porphyry copper-molybdenum or polymetallic vein deposits based on the geochemical data from reconnaissance stream-sediment samples, the presence of molybdenum-bearing veinlets, and the high level of pluton exposure (Light and Rinehart, 1989). Evidence of widespread hydrothermal alteration associated with the intrusion is lacking however. 


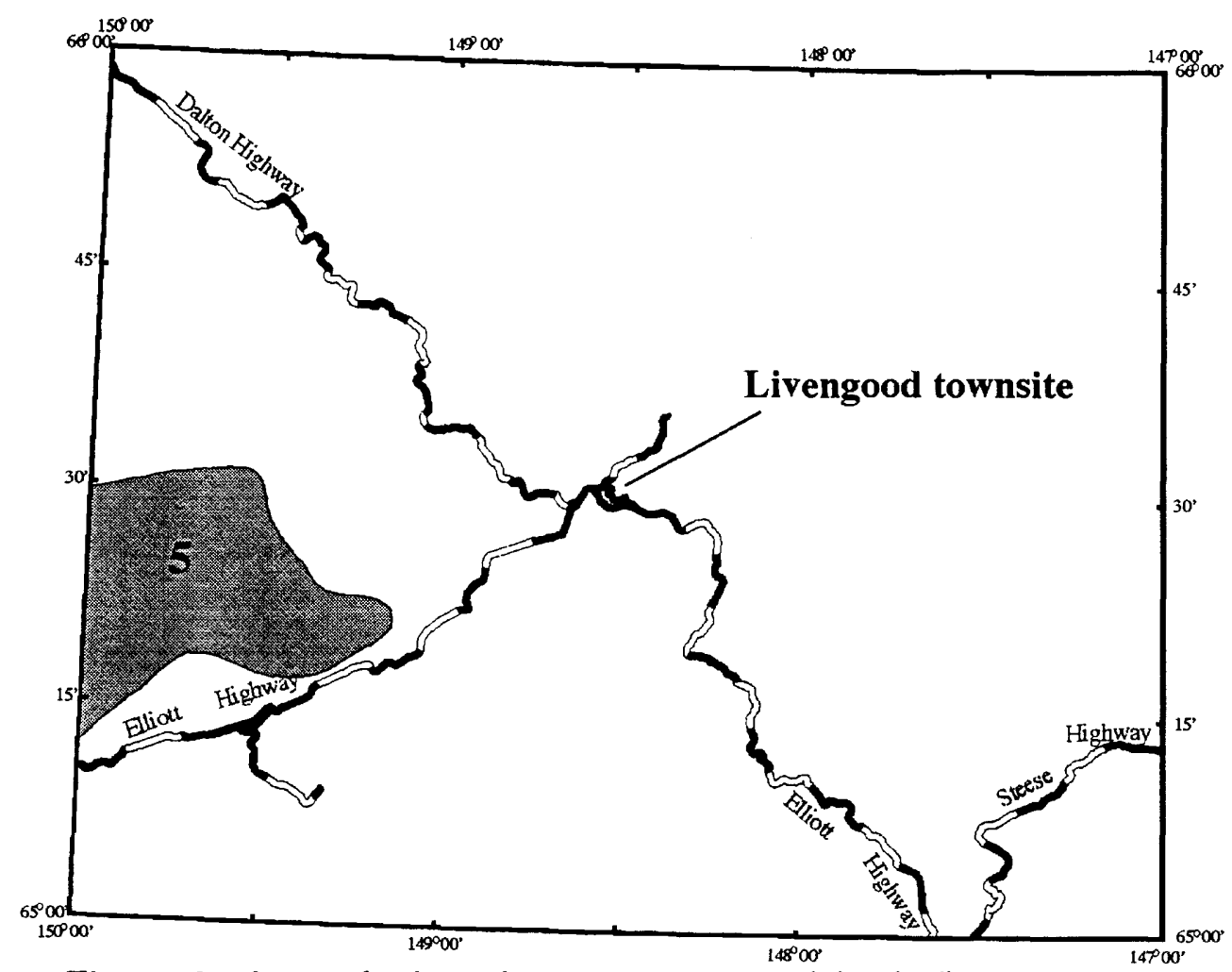

Figure 6. Area of mineral resource tract 5 (shaded).

\section{TIN GREISEN DEPOSITS}

Tin greisen deposits consist of veinlets, stockworks, lenses, pipes and breccias in siliceous ( $>70$ percent $\mathrm{SiO}_{2}$ ) leucogranites (Reed, 1986). Tin occurs as the mineral cassiterite which is associated with a unique alteration assemblage called greisen that consists of quartz, muscovite, topaz, fluorite and tourmaline, that modifies the host granitoid and, in many instances, its adjacent wall rock. The area surrounding the Cache Mountain pluton (tract 6, figure 7) is identified as being permissive for the occurrence of undiscovered tin greisen deposits. The Cache Mountain pluton exhibits 
the following attributes common among tin-bearing granites: 1) silica-rich leucogranite, 2) peraluminous and potassic composition, 3) presence of topaz, tourmaline, fluorite, and muscovite, 4) presence of miarolitic cavities, 5) presence of anomalous values of tin in the bedrock at 15 localities in the pluton, 6) anomalous concentrations of $\mathrm{W}, \mathrm{Pb}, \mathrm{Zn}$, $\mathrm{Cd}, \mathrm{Ag}, \mathrm{B}, \mathrm{Bi}$, and $\mathrm{Be}$ in and around the pluton, and 7) abundant cassiterite recovered from heavy-mineral pan concentrate samples from streams draining the exposed pluton. The occurrence of tin at Cache Mountain was first noted by Chapman and Weber (1972). Later, brief reconnaissance mapping and sampling by the U.S. Bureau of Mines (Dean Warner, USBM, 1984, unpublished report) showed 1,050 ppm tin from weakly altered fine-grained granite in the southeast part of the pluton. A pan concentrate sample from Brigham Creek yielded 2,390 ppm tin. The earlier discovery of tin in the Rocky Mountain (Lime Peak) pluton, $20 \mathrm{~km}$ to the northeast (Circle quadrangle), had prompted the investigation at Cache Mountain. Warner stated that the Cache Mountain pluton is "identical to the Lime Peak pluton", that is, a composite pluton consisting of distinct phases that have correlative counterparts in the Lime Peak pluton. With the exceptions of an aplitic phase and a hypabyssal porphyritic phase both of which were observed to cut coarser-grained varieties, gradational variation commonly over a few meters among several textural types, has since been found to be the pattern most typical of relations among constituent rocks in the Cache Mountain pluton (Weber and others, 1988). There is insufficient evidence to conclude that Cache Mountain represents a composite pluton.

West of Cache Mountain, between Fossil Creek and Beaver Creek, the occurrance of several small isolated outcrops of granitic rock similar to that at Cache Mountain indicate the possibility of a buried granitic intrusion. This inferred pluton, if related to the Cache Mountain intrusion could also represent a potential for additional tin greisen resources. 


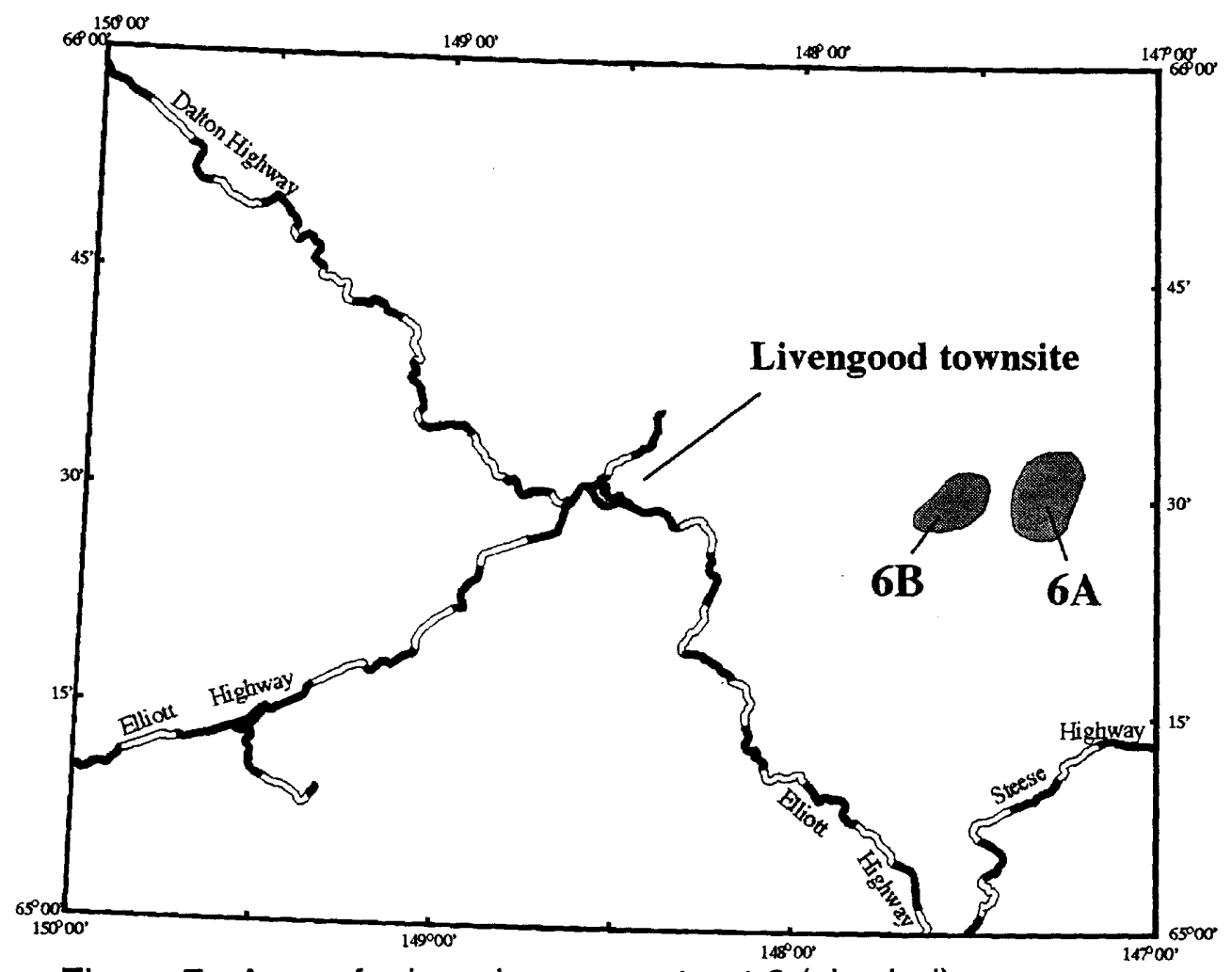

Figure 7. Area of mineral resource tract 6 (shaded).

\section{THORIUM-RARE-EARTH VEIN DEPOSITS}

Thorium-rare-earth vein deposits consist of various thorium and rare-earth minerals in quartz-potassium feldspar-iron-oxide gangue in veins along fractures in and adjacent to alkaline rocks (Staatz, 1992). Although most of the veins are tabular, some are lenticular, and in some cases, vein material is composed of interstitial to brecciated unmineralized country rock. The principal ore minerals are thorite and monazite associated with brockite, allanite, and bastnaesite. Tract 7 (figure 8) is identified as being permissive for the occurrence of thorium-rare-earth vein deposits. The primary evidence is the occurrence of the Roy Creek prospect, an alkalic syenite-hosted thorium-rare-earth vein system discovered as a result of the U.S. Bureau of Mines report of anomalous uranium 
concentration in the Mount Prindle area (see table 1). In December, 1978, MAPCO, Inc., announced the discovery of surface samples containing 5 to 7 percent uranium from the "Mt. Prindle area." The samples were presumably from the Roy Creek prospect, although the site is $30 \mathrm{~km}$ west of Mt. Prindle. The prospect is exposed in a ridge that separates the upper reaches of Roy and O'Brien Creeks where the host plutonic body is exposed. The host plutonic body has been explored extensively by surface scraping and trenching, excavation of exploration pits, and diamond drilling (Burton, 1981). It is estimated that a total of 11,000 feet of drilling occurred during the evaluation of the prospect (Weber and others, 1988). The prospect lies within a syenite complex which is comprised of five distinct varieties of rock types that include quartz alkali-feldspar syenite, "quartz-bearing" alkali-feldspar syenite, nepheline-bearing alkali-feldspar syenite, and shonkinite (Armbrustmacher, 1989). The presence of miarolitic cavities and of vugs in the veins indicate that both the magma and the veins were emplaced at shallow depth. The thorium and rare-earth minerals occur mainly in the veins. Samples taken from the veins contain high values of both thorium and cerium-group rare-earths (Weber and others, 1988). Concentrate samples from streams draining the Roy Creek pluton contain thorite, allanite, and sapphire corundum (Tripp, 1988).

\section{SIMPLE ANTIMONY DEPOSITS}

Simple antimony deposits consist of stibnite veins, pods, and disseminations in or adjacent to brecciated or sheared fault zones, in sedimentary, volcanic, and metamorphic rocks adjacent to granitic plutons, in contact aureoles around granitic plutons, and peripheries of felsic intrusive bodies (Bliss and Orris, 1986; Nokleberg and others, 1987). The two most notable examples of antimony deposits in the Livengood quadrangle are the Scrafford deposit in tract 4a (Robinson and Bundtzen, 1982) and the 


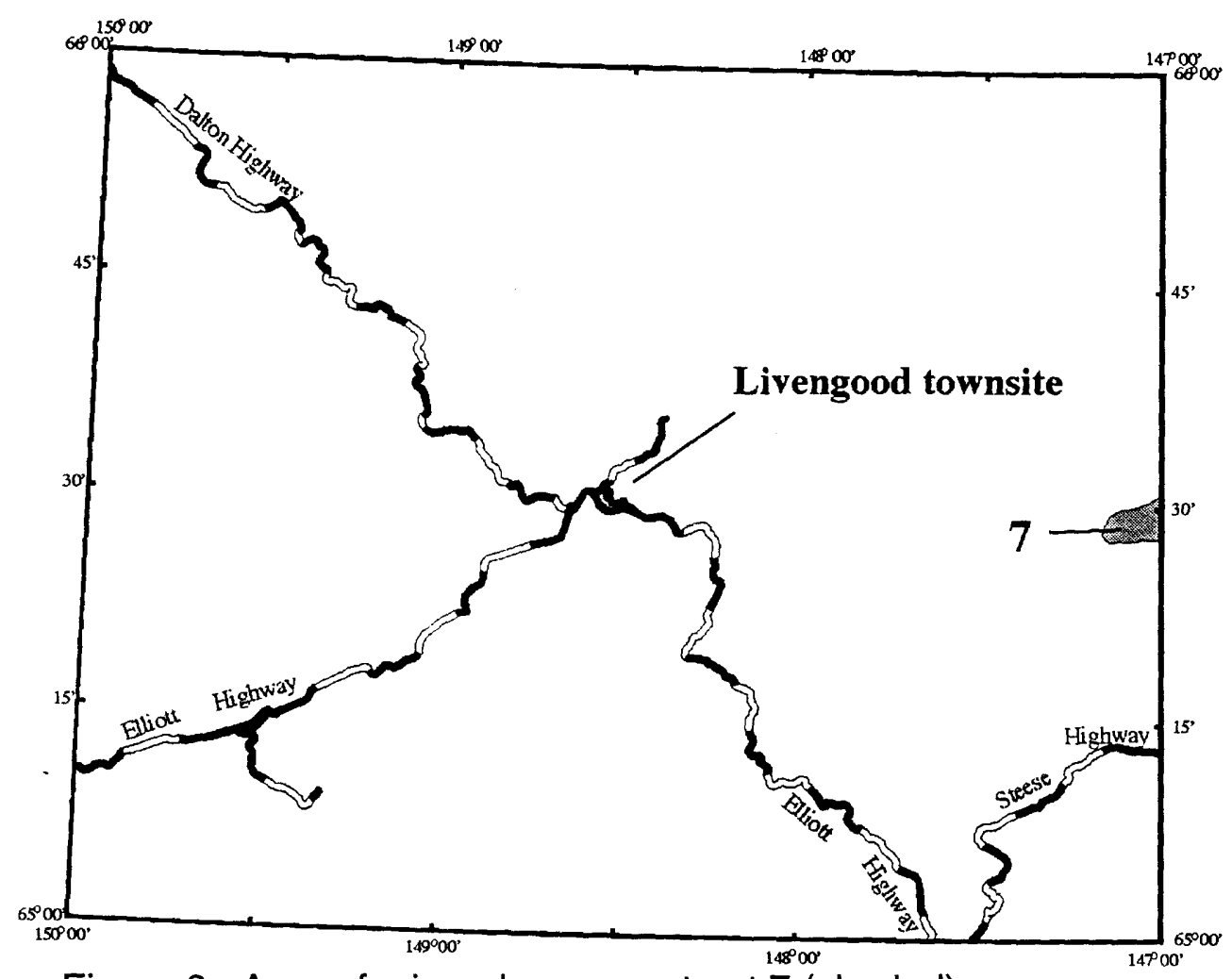

Figure 8. Area of mineral resource tract 7 (shaded).

Sawtooth Mountain deposit (Nokleberg and others, 1987) in tract 5. It has been estimated that over 900 metric tons of antimony was produced from the Scrafford deposit (Robinson and Buntzen, 1982) and over 300 metric tons of antimony from the Sawtooth Mountain deposit (R.M. Chapman, USGS, written commun., 1985). Within the Livengood quadrangle, simple antimony deposits are identified as being permissive in tract $4 \mathrm{a}$ and tract 5 . Within tract 10a, the occurrence of antimony has been described by Robinson and others (1990) as representing the last of four episodes of volatile transport, which consists of late stage monomineralic veins in which stibnite occurs in gash veins and in isolated podiform lenses. Stibnite is a common mineral found in many of the lode gold deposits in the tract. Further study may show that the antimony 
deposits are more closely related to the gold-antimony deposit type described recently by Berger (1993).

Within tract 4 , in addition to the Sawtooth Mountain antimony deposit, there are several other known occurrences of stibnite, but no record of any other production.

\section{PORPHYRY MOLYBDENUM LOW-FLUORINE DEPOSITS}

Porphyry molybdenum low-fluorine deposits consist of quartz-molybdenite stockwork veinlets in felsic porphyry and adjacent country rock (Theodore, 1986; Nokleberg and others, 1987). The porphyries range in composition from tonalite to granodiorite to monzogranite. Associated metallic minerals are pyrite, scheelite, chalcopyrite, and tetrahedrite. Alteration is potassic grading outward to propylitic, sometimes with a phyllic and argillic overprint. The best example of a porphyry molybdenum low-fluoride deposit in Alaska is the Quartz Hill deposit in southeast Alaska (Nokleberg and others, 1987). Tract 5 and tract 2 are identified as being permissive for the occurrence of porphyry molybdenum low-fluoride deposits. As described earlier for polymetallic vein deposits, tract 5 contains the Huron Creek pluton that has been described by Light and Rinehart (1989) as having a potential for porphyry copper-molybdenum deposits. Their conclusion was based on the geochemical data from reconnaissance stream-sediment samples, the presence of molybdenum-bearing veinlets, and the high level of pluton exposure. The absence of chalcopyrite favors a porphyry-molybdenum model type. Regardless of which deposit model is preferred, there is no evidence in the quadrangle of widespread hydrothermal alteration associated with the Huron Creek intrusion.

Tract 2 consists of scattered exposures of plutonic rocks, the largest being granodiorite bodies parallel to the regional structural grain. Ten to fifteen percent of the outcrop area is occupied by small bodies of porphyritic, quartz-feldspar granite that 
locally intrude the granodiorite. A thin metamorphic aureole in the Fairbanks schist unit forms a zone several hundred meters wide in which the recrystallized metamorphic rocks are harder and denser. The presence of molybdenum in the Silver Fox mine was first reported by Mowatt (1974). Molybdenite occurs as disseminated crystals and as coatings along contacts between a quartz stockwork, that is exposed in the underground workings, and the country rock. The mineral assemblage in the quartz stockwork consists of quartz, molybdenite, and scheelite; pyrite occurs irregularly within the country rock. Potassic alteration is present within the stockwork and is surrounded by zones of minor to moderate sericitization and locally chloritization and argillization. Sherman (1983), in his study of the occurrence, speculated that the mineralization at the Silver Fox mine represents a weakly developed molybdenum-porphyry system of the granodiorite type.

\section{SERPENTINE-HOSTED ASBESTOS AND PODIFORM CHROMITE DEPOSITS}

The reason for considering these types of deposits together is that asbestos, $\mathrm{Ni}, \mathrm{Cr}$, and PGE have all been reported, often associated together in similar rocks, in the Livengood quadrangle. Tract 8 (figure 9) is identified as being permissive for these deposit types. Serpentine-hosted asbestos deposits consist of stockworks of asbestos in serpentinized ultramafic rocks (Page, 1986). The depositional environment is usually an ophiolite sequence, with or without later deformation or intrusion by igneous rocks. The major rock types are serpentinite, dunite, harzburgite, and pyroxenite. An example of a serpentine-hosted asbestos deposit in Alaska is the Fortymile deposit in east-central Alaska (Foster and Keith, 1974).

Podiform chromite deposits consist of podlike masses of chromitite in ultramafic parts of ophiolite complexes (Albers, 1986). Examples of this type of deposit are the 
Iyikrok Mountain, Misheguk Mountain, and Avan deposits in the northwestern Brooks Range, the Kaiyuh River deposit in west-central Alaska, and the Halibut Bay, Claim Point, and Red Mountain deposits in southern Alaska (Nokleberg and others, 1987).

Serpentinized ultramafic rocks form a long, narrow, discontinuous northeast-trending belt across the quadrangle from northwest of Manley Hot Springs in the Tanana quadrangle to Beaver Creek. The ultramafic rocks are highly serpentinized and the original mineralogy is difficult to determine. Varied compositions reported for the unit include serpentinized peridotite interlayered with hypersthene gabbro and hornblende gabbro (Bundtzen, 1983), serpentinized harzburgite and associated minor dunite (Loney and Himmelberg, 1988), and clinopyroxenite gabbro, microgabbro, and diorite (Weber and others, 1988). Loney and Himmelberg (1988) interpreted the original petrology (harzburgite and minor dunite) and texture to be consistent with that of a dismembered ophiolite sequence. They cite the long, narrow thrust-bounded distribution and the presence of tectonized rodingite (medium- to coarse-grained, commonly enriched gabbroic rock) blocks as additional evidence supporting an ophiolite origin. K-Ar dates on diorites intruding the serpentinite indicate a minimum age for the serpentinite at $643 \mathrm{Ma}$ (F.R. Weber, USGS, oral communication, 1990).

The serpentinized mafic and ultramafic units northeast of Livengood, between the Tolovana River and Beaver Creek contain locally anomalous concentrations of $\mathrm{Cr}$ and $\mathrm{Ni}$ in rock samples (Bie and others, 1993) as well as in stream sediment samples from drainages flanking the unit (Arbogast and others, 1991). In addition to $\mathrm{Cr}$ and $\mathrm{Ni}$, Foster (1969) reported $\mathrm{Pt}$ (up to $0.012 \mathrm{ppm}$ ), and $\mathrm{Pd}$ (up to $0.011 \mathrm{ppm}$ ) from this area.

Anomalous concentrations of $\mathrm{Cr}$ and $\mathrm{Ni}$ have been reported from several of the placer deposits in the vicinity of Livengood dome (Cobb, 1974, 1975). Barker (1978) reported a Ni-Pt occurrence in the mafic-ultramafic unit near Beaver Creek. Mertie (1937) reported a platinum-gold nugget recovered from one of the placer deposits in the Livengood area. Cathrall and others (1987) and McDanal and others (1988) reported Pt as a 
trace-element component of gold nuggets from the Tolovana and Rampart mining districts. It is possible that some of the Pt in gold nuggets in the placer deposits may have been derived from the ultramafic rocks, and remobilized during emplacement of the felsic dikes and plutons from which the placer deposits were derived. Pyroxenite cobbles containing veinlets of asbestos with fibers as much as one-half inch long were reported along Beaver Creek (Barker, 1978). Despite the exploration for $\mathrm{Cr}$ and $\mathrm{Ni}$ in the quadrangle during the seventies, no further occurrences of asbestos have been reported. Because of the relatively thin $(<2,000 \mathrm{~m})$ mafic-ultramafic complex, the separate trend and different age rock from ultramafic rocks which host the Fortymile deposit, and the lack of any discovery of significant amounts of asbestos, $\mathrm{Cr}$, Ni, or PGE despite exploration in an area in which the rocks are well exposed, it is concluded there is a low probability of occurrence of serpentine-hosted asbestos deposits or podiform chromite deposits.

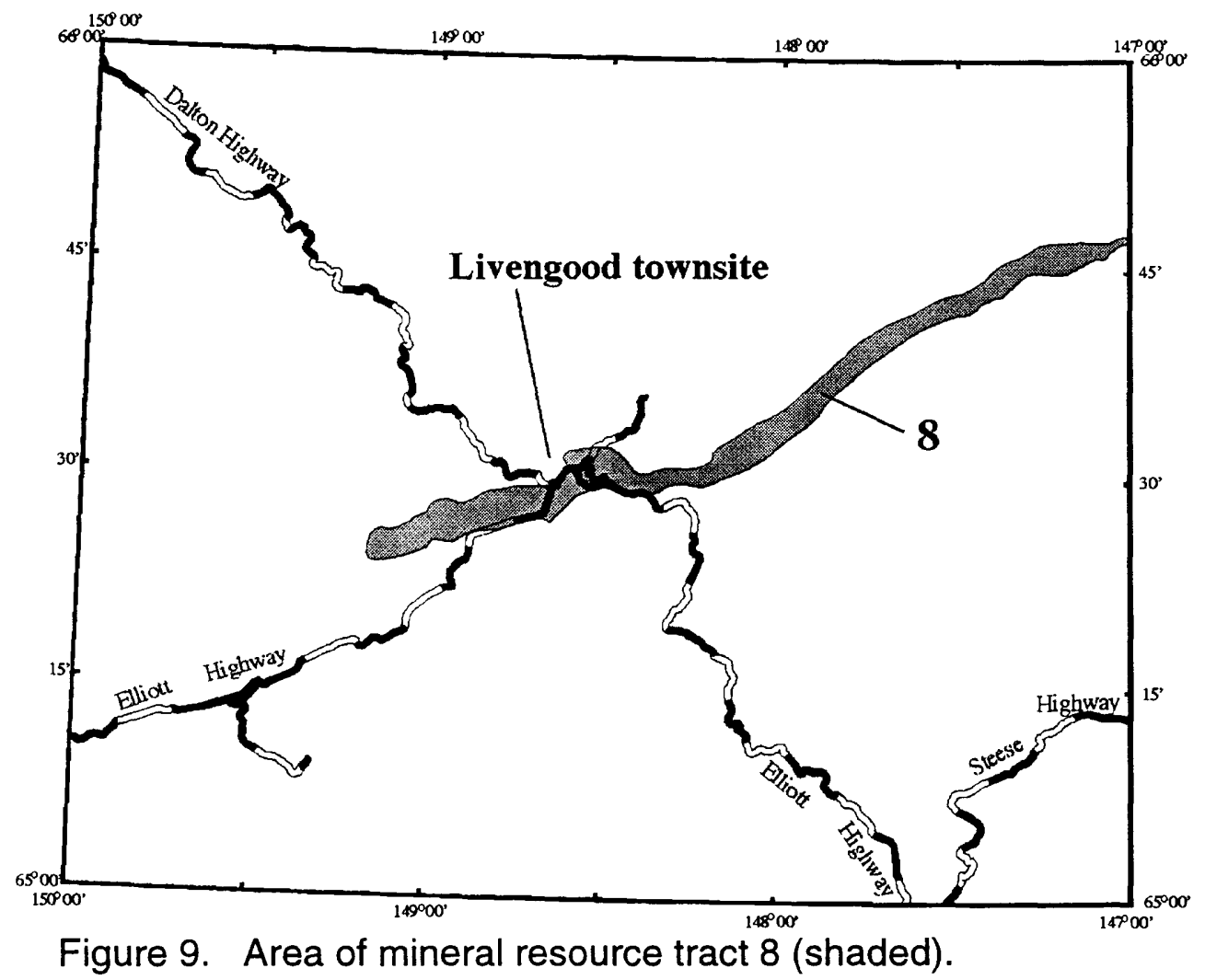




\section{UNCLASSIFIED METALLIFEROUS DEPOSITS}

Tract 9 (figure 10) is underlain principally by the Schwatka unit which consists mainly of mafic volcanic rocks, limestone, and minor clastic sedimentary rocks. Investigations of the mineral potential date back to early 1978. Prior to the investigation, there was no recorded information concerning mineralization or mining-claim locations. A preliminary assessment of the area conducted by the U.S. Bureau of Mines (Barker, 1980) revealed the presence of zinc, lead, and barium mineralization associated with volcaniclastic breccia in a cherty quartz matrix (see table 1). Various secondary carbonate coatings are also common and, in some of these, smithsonite was identified. Samples contain up to 10 percent zinc and 15 percent lead. No anomalous levels of copper or silver were detected. The area was later extensively explored and over 170 claims filed and mineralization reported, but no further details were released.

Tract 10 (figure 11) is underlain principally by the Fossil Creek Volcanics and the Globe unit. The Fossil Creek Volcanics consist of alkali basalt, agglomerate, shale, chert, and limestone, and all but the basalt intruded by gabbro. The Globe unit consists of vitreous quartzite, phyllite, and slate. Although galena, sphalerite, stibnite, pyrite, cinnabar, cassiterite, scheelite and barite are present in pan-concentrate samples along Beaver Creek and the Tertiary felsic intrusion at Cache Mountain is nearby, there is insufficient evidence to suggest a genetic relation between the intrusion and the fractures, shears, and faults which are filled, either partially completely with sulfide minerals in the Fossil Creek Volcanics and the Globe unit. 


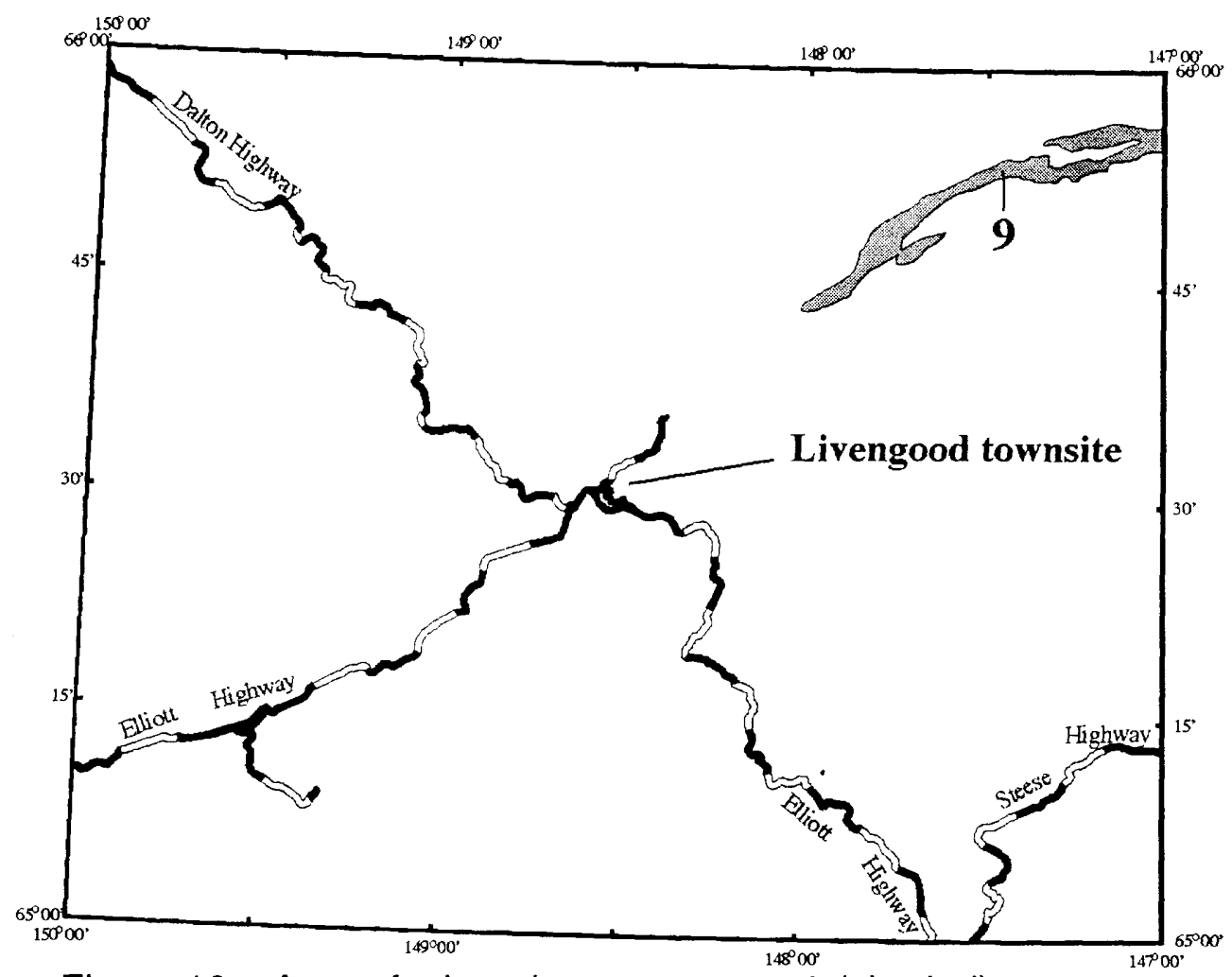

Figure 10. Area of mineral resource tract 9 (shaded).

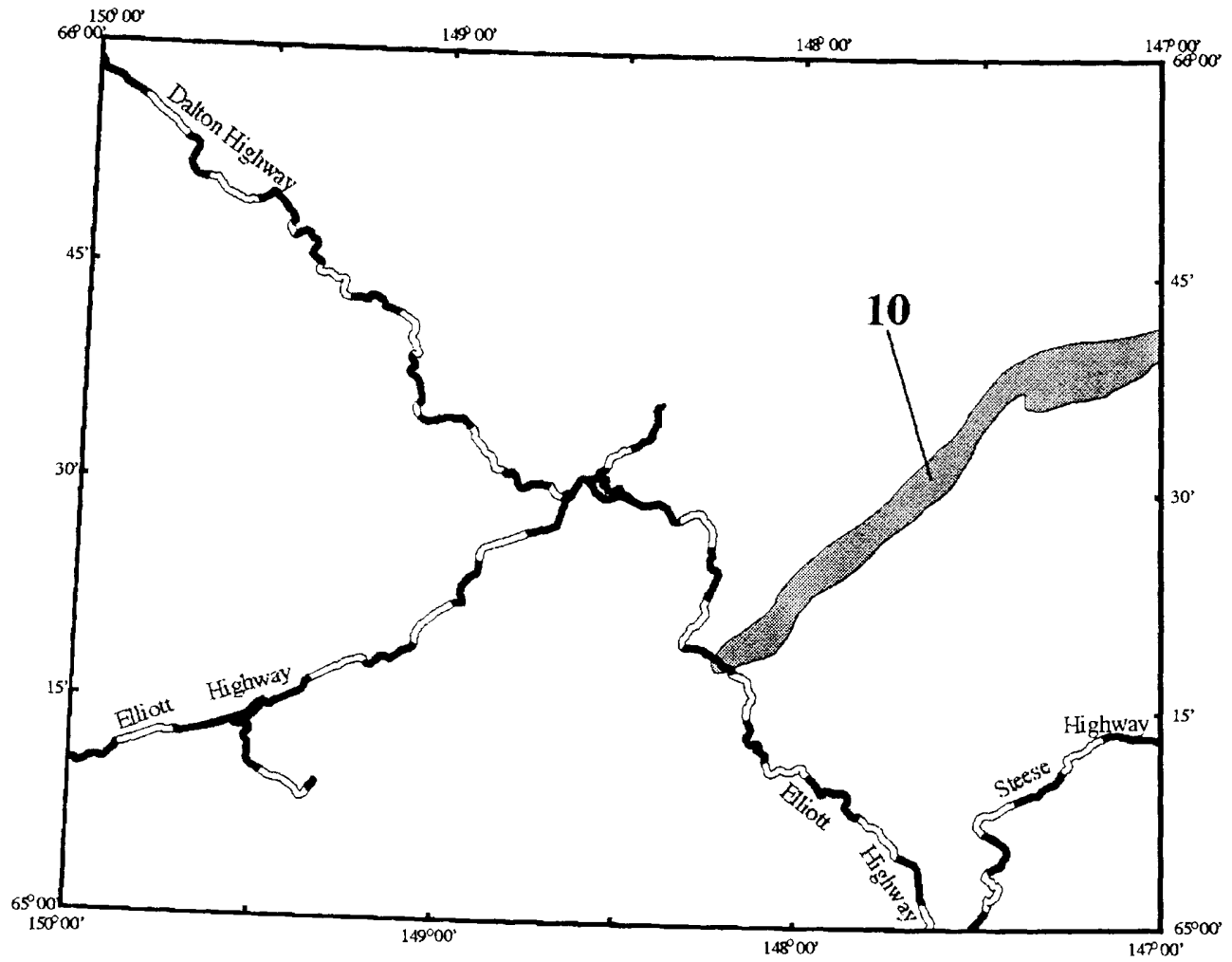

Figure 11. Area of mineral resource tract 10 (shaded). 


\section{NONMETALLIFEROUS DEPOSITS}

Coal is one of the nonmetalliferous deposits that have been explored in the Livengood quadrangle with the idea of commerical production. Coal exposed along the Yukon River directly opposite the mouth of Hess Creek in the northwestern part of the quadrangle has been described in the early literature (Collier, 1903; Mertie, 1937). The coal occurs as part of a sequence of Tertiary volcanic and sedimentary rocks (Tvs) that are now considered to be Eocene in age (F.R. Weber, USGS, oral comm.). Discovered in 1897, the coal was mined and used on river steamers at the turn of the century. At least 1000 tons of bituminous coal were mined prior to 1902 (Barnes, 1967). There has been no further known development or exploration for coal in this area. The only other known occurrence of carboneous material in the quadrangle was reported by Tourtelot (USGS, oral comm.) who described carboneous material in the spoil pits along Fish Creek in the southeasternmost part of the quadrangle. It is unknown if such material could be classified as coal.

The quadrangle includes parts of Mesozoic and Cenozoic basins that were evaluated for their petroleum resource potential as part of the Alaska onshore national assessment (Kirschner, 1988; Magoon and Kirschner, 1990). Mesozoic basinal deposits, characterized as flysch belts, extend southwestward across the quadrangle and consist of conglomerate, sandstone, siltstone, and shale. In the national assessment, the flysch basins in which the basinal deposits in the quadrangle are considered a part, were assessed as having little petroleum potential and were considered economic basement (Magoon and Kirschner, 1990).

Overlying the Mesozoic deposits are Cenozoic deposits that occur in the northernmost and the southwesternmost parts of the quadrangle. The Cenozoic deposits in the northernmost part of the quadrangle are a part of the Yukon Flats basin, a large alluvial and lake-dotted lowland bounded on the north by the Brooks Range and 
on the south by the Yukon-Tanana upland. Based on gravity modeling and preliminary seismic data, the Yukon Flats basin may have up to $4.5 \mathrm{~km}$ of Cenozoic fill (Hite and Nakayama, 1980). Seeps or other direct indications of hydrocarbons are unknown in the Yukon Flats basin. Because of the presence of nonmarine Tertiary lacustrine beds and coal beds, the optimistic evaluation was that gas resources of economic importance for local consumption could be present (Magoon and Kirschner, 1990).

In the southwesternmost part of the quadrangle, Cenozoic deposits occur that are a part of the Nenana basin (usually called "the Minto flats"), a large alluvial and swampy lowland north of the central Alaska Range and south and west of the Yukon-Tanana upland. The Minto gravity low in excess of 50 milligals suggests about $3 \mathrm{~km}$ of late(?) Cenozoic fill (Magoon and Kirschner, 1990). The most likely source rocks, that is, lacustrine shale for oil, and coal-beds for gas, are unknown within the quadrangle and for this reason, the potential for either petroleum or gas is negligible.

High-calcium limestone ( $>93$ percent carbonate content) occurs in the Tolovana Limestone that comprises the core of the White Mountains in the central part of the quadrangle. The thickness of the Tolovana Limestone is in excess of $1220 \mathrm{~m}(4,000 \mathrm{ft})$. The purity of the limestone is consistently very high. Based on the analyses of 10 grab samples, the average is 98.56 percent calcium carbonate (McCammon and others, 1988). An estimate of the endowment of high-calcium limestone in the quadrangle is 24 billion metric tons. 


\title{
QUANTITATIVE ESTIMATES OF UNDISCOVERED METALLIC RESOURCES
}

\author{
By
}

\author{
Richard B. McCammon
}

Estimates of the number of undiscovered deposits at the 90th, the 50th, the 10th, the 5th, and the 1st percent confidence level are listed in table 3 for each deposit type within the tracts described in table 2. Estimates of the numbers of undiscovered deposits are based on the synthesis of all the available geologic, geochemical, geophysical, and mineral-resource data and the mineral deposit models described in Cox and Singer (1986) and in Bliss (1992). The methods used to estimate the number of undiscovered deposits in each tract were those described by Singer (1993). In estimating the number of undiscovered deposits, the criteria used for delineating each tract were combined with other factors such as the spatial density, extent of exploration, and the strength of the evidence. For the most part, estimates of the number of undiscovered vein type deposits were based on local deposit extrapolations consisting of the projection of deposit density in the well explored portion of the tract to the less well explored portion of the tract. Estimates of the number of undiscovered porphyry type deposit were based more on the strength of the evidence that suggested the presence of undiscovered deposits combined with the knowledge of the occurrence of such deposits in nearby areas. Lack of sufficient data or more direct evidence precluded estimating the number of undiscovered deposits for all of the tracts. 


\section{Table 2. Undiscovered mineral resources in the Livengood quadrangle, Alaska}

Model

Tract Undiscovered deposit type No. ${ }^{* \star}$

Plutonic porphyry gold

Low-sulfide Au-quartz veins

Polymetallic veins

2 Porphyry-Mo low-F

Plutonic porphyry gold

3a Placer Au

3b Placer Au

3c Placer Au
Description of deposit type

Stockwork of gold-bismuth-

molybdenum-tungsten in felsic porphyry

36a Gold in massive persistent quartz veins mainly in regionally

metamorphosed volcanic rocks

22c Fractures, shears, or faults which are Presence of numerous felsic porphyritic dikes

filled, either partially or completely, with

sulfide minerals and associated

silicates, carbonates, or sulfates

21b Quartz-molybdenite stockwork veinlets Quartz-feldspar porphyritic peraluminous granite that locally in felsic porphyry and adjacent country intrudes granodioriteMinor to moderate sericitization and rock locally chloritization and argillizationStockwork sulfide-bearing quartz veinsMolybdenite along contacts between quartz veins and wallr

$20 \mathrm{~d} .1$ Stockwork of gold-bismuthmolybdenum-tungsten in felsic porphyry

Scattered exposures of felsic plutonic rocks, the largest being granodiorite bodies elongate parallel to regional structure that hosts the Fort Knox depositPresence of gold placer deposits

39a Elemental gold and platinum-group Numerous placer gold depositsgold in stream-sediment alloys in grains and nuggets in gravel, samples

sand, silt, and clay, and their

consolidated equivalents

39a Elemental gold and platinum-group Numerous placer gold depositsgold in stream-sediment alloys in grains and nuggets in gravel, samples

sand, silt, and clay, and their

consolidated equivalents

39a Elemental gold and platinum-group Numerous placer gold depositsgold in stream-sediment alloys in grains and nuggets in gravel, samples

sand, silt, and clay, and their

consolidated equivalents 


\section{Table 2 (continued). Undiscovered mineral resources in the Livengood quadrangle, Alaska}

\section{Tract Undiscovered deposit type \\ 4a Low-sulfide Au-quartz veins \\ No. ${ }^{* \star}$

$36 a$

(1) \\ metamorphosed volcanic rocks}

Simple Sb

Low-sulfide Au-quartz veins

5. Porphyry-Mo low-F

Polymetallic veins

Simple Sb

6

Sn greisen

27d Stibnite veins, pods, and

disseminations in or adjacent to

brecciated or sheared fault zones

36a Gold in massive persistent quartz

veins mainly in regionally metamorphosed volcanic rocks rock filled, either partially or completely, with

sulfide minerals and associated

silicates, carbonates, or sulfates

27d Stibnite veins, pods, and

disseminations in or adjacent to

brecciated or sheared fault zones

15c Disseminated cassiterite, and 21b Quartz-molybdenite stockwork veinlets in felsic porphyry and adjacent country

22c Fractures, shears, or faults which are cassiterite-bearing veinlets, potassic compositionPresence of topaz, tourmaline, fluorite, stockworks, lenses, pipes, and breccia and muscovitePresence of miarolitic cavitiesAnomalous in greisenized granite

11c Thorium and rare-earth minerals in felsic gangue in veins
Criteria used to delineate permissive tract

Quartz fissure veins with gold in interlayered micaceous quartzite, graphitic schist, pelitic schist, chlorite-actinolite greenschist, calc-schist, and marbleSeventy-eight known lode occurrences, thirty with production

Massive stibnite along east-west-striking shear

zoneDisseminated quartz stockwork and veinlets with arsenopyrite and stibnite in feldspathic quartzite and quartz mica schist

Numerous placer gold depositsArea underlain by metavolcanic rocks which host low-sulfide Au quartz veinsProximity of Tertiary felsic intrusion

Quartz monzonite emplaced in mainly norteast-trending contact-metamorphosed sedimentary rocksModerate sericitization of plagiocase cores and replacement of biotite by chloritePresence of molybdenite-bearing quartz

veinletsAbundant scheelite and barite, $\mathrm{mi}$

See aboveAnomalous values of $\mathrm{As}, \mathrm{B}, \mathrm{Cu}, \mathrm{Pb}, \mathrm{Mo}, \mathrm{Sn}$, and $\mathrm{W}$ th in heavy-mineral concentrates

Massive stibnite orebody in vertical cylinder localized along contact between quartz monzonite and argilliteStibnite occurrences at scattered locations in and around nearby quartz monzonite bodies

Silica-rich leucogranite having peraluminous and relatively values of $\mathrm{Sn}$ in bedrockAnomalous concentrations of $\mathrm{W}, \mathrm{Pb}$, $\mathrm{Zn}, \mathrm{Cd}, \mathrm{Ag}, \mathrm{B}, \mathrm{Bi}$, and

Occurrence of alkalic, syenite-hosted U/Th RRE deposit (Roy Creek Prospect)Anomalous values of Th and cerium-group REE in exposed veins 


\section{Table 2 (continued). Undiscovered mineral resources in the Livengood quadrangle, Alaska}

\begin{tabular}{|c|c|c|c|c|}
\hline Tract & Undiscovered deposit type & $\begin{array}{l}\text { Model } \\
\text { No. }{ }^{\star \star}\end{array}$ & Description of deposit type & Criteria used to delineate permissive tract \\
\hline & Podiform chromite & $8 a$ & $\begin{array}{l}\text { Podlike masses of chromitite in } \\
\text { ultramafic parts of ophiolite complexes }\end{array}$ & $\begin{array}{l}\text { See aboveAnomalous concentrations of } \mathrm{Cr} \text { and } \mathrm{Ni} \text { in rock } \\
\text { samples and in stream-sediment samplesReported } \mathrm{Pt} \text { (up to } \\
0.012 \mathrm{ppm} \text { ) and } \mathrm{Pd} \text { (up to } 0.011 \mathrm{ppm} \text { ) Reported platinum and } \\
\text { gold nugget recovered from placer deposit }\end{array}$ \\
\hline 9 & Unclassified & $22 \mathrm{c}$ & $\begin{array}{l}\text { Fractures, shears, or faults which are } \\
\text { filled, either partially or completely, with i } \\
\text { sulfide minerals and associated } \\
\text { silicates, carbonates, or sulfates }\end{array}$ & $\begin{array}{l}\text { Presence of smithsonite associated with volcaniclastic breccia } \\
\text { in cherty quartz matrixMajor southwest-trending faultsMinor } \\
\text { traces of galena and sphalerite in brecciated limestone and } \\
\text { dolomite }\end{array}$ \\
\hline 10 & Unclassified & $22 c$ & $\begin{array}{l}\text { Fractures, shears, or faults which are } \\
\text { filled, either partially or completely, with } \\
\text { sulfide minerals and associated } \\
\text { silicates, carbonates, or sulfates }\end{array}$ & $\begin{array}{l}\text { Presence of galena, sphalerite, stibnite, pyrite, cinnabar, } \\
\text { cassiterite, and abundant scheelite and barite in heavy-mineral } \\
\text { pan-concentrate samples along Beaver CreekProximity of } \\
\text { Tertiary felsic intrusion at Cache Mountain }\end{array}$ \\
\hline
\end{tabular}

** Model numbers from Cox and Singer (1986) and Bliss (1992) 
Table 3. Estimates of the number of undiscovered deposits in the Livengood quadrangle, Alaska

Greatest number of Undiscovered deposits with probability $\mathrm{P}$ or higher

\begin{tabular}{|c|c|c|c|c|c|c|c|}
\hline \multirow[t]{2}{*}{ Tract } & \multirow[t]{2}{*}{ Undiscovered deposit type } & \multirow[t]{2}{*}{ Model No } & \multicolumn{5}{|c|}{$\mathrm{P}$} \\
\hline & & & 0.90 & 0.50 & 0.10 & 0.05 & 0.01 \\
\hline \multirow[t]{3}{*}{1} & Plutonic porphyry gold & 20d.1 & 0 & 0 & 1 & 1 & 1 \\
\hline & Low-sulfide Au-quartz veins & $36 a$ & 0 & 1 & 1 & 1 & 2 \\
\hline & Polymetallic veins & $22 c$ & 0 & 1 & 1 & 1 & 2 \\
\hline \multirow[t]{2}{*}{2} & Porphyry-Mo low-F & $21 b$ & 0 & 0 & 0 & 1 & 1 \\
\hline & Plutonic porphyry gold & 20d.1 & 0 & 0 & 1 & 1 & 2 \\
\hline $3 a$ & Placer Au & $39 a$ & 3 & 4 & 5 & 6 & 7 \\
\hline $3 b$ & Placer $\mathrm{Au}$ & $39 a$ & 2 & 3 & 4 & 4 & 5 \\
\hline $3 c$ & Placer Au & $39 a$ & 2 & 3 & 4 & 4 & 4 \\
\hline \multirow[t]{2}{*}{$4 a$} & Low-sulfide Au-quartz veins & $36 a$ & 1 & 2 & 2 & 3 & 4 \\
\hline & Simple Sb & $27 d$ & 1 & 2 & 2 & 2 & 3 \\
\hline $4 b$ & Low-sulfide Au-quartz veins & $36 a$ & 1 & 1 & 2 & 2 & 3 \\
\hline \multirow[t]{3}{*}{5} & Porphyry-Mo low-F & $21 b$ & 0 & 0 & 0 & 0 & 1 \\
\hline & Polymetallic veins & $22 c$ & 0 & 0 & 1 & 1 & 1 \\
\hline & Simple Sb & $27 d$ & 1 & 1 & 2 & 2 & 3 \\
\hline 6 & Sn greisen & $15 c$ & 0 & 0 & 0 & 1 & 1 \\
\hline 7 & Thorium-rare-earth veins & $11 \mathrm{c}$ & 0 & 0 & 1 & 1 & 1 \\
\hline \multirow[t]{2}{*}{8} & $\begin{array}{l}\text { Serpentine-hosted } \\
\text { asbestos }\end{array}$ & $8 d$ & & Not & estimated & & \\
\hline & Podiform chromite & $8 a$ & & Not & estimated & & \\
\hline 9 & Unclassified & - & & Not & estimated & & \\
\hline 10 & Unclassified & - & & Not & estimated & & \\
\hline
\end{tabular}


Probabilistic estimates of the remaining endowments of metallic resources were generated by combining the estimates of the numbers of undiscovered deposits with the grade and tonnage models for each deposit type in the U.S. Geological Survey's MARK3 Simulator (Root and others, 1992). The input for each tract consists of the estimates of the numbers of undiscovered deposits and the grade and tonnage model data for each deposit type. Output from the simulator includes estimates of total metal endowments and deposit tonnages in rank order based on 4,999 simulations. Metal endowments for the 90th, 50th, 10th, 5th, and 1st percentiles of the simulated distributions for each metal by deposit type within each tract are shown in table 4 . The estimates of metal endowments represent in-place undiscovered resources. The estimates of the total metal endowments within the quadrangle are shown in table 5. The gross in-place values of these resources are shown in table 6. The gross in-place values were calculated assuming 5-year average metal prices for the years 1988-1992 using the data in the Mineral Commodity Summaries (U.S. Department of the Interior Bureau of Mines, 1993). The 5-year average metal prices are the following: copper, $\$ 1.18 / \mathrm{lb}$ or $\$ 2,605 /$ metric ton; gold, $\$ 384.22 /$ oz or $\$ 12,352,878 /$ metric ton; silver, $\$ 4.98 /$ oz or $\$ 160,110 /$ metric ton; zinc, $\$ 0.66 / \mathrm{lb}$ or $\$ 1,449 /$ metric ton; lead, $\$ 0.38 / \mathrm{lb}$ or $\$ 847 /$ metric ton; molybdenum, $\$ 6.68 / \mathrm{kg}$ or $\$ 6,680 /$ metric ton; antimony, $\$ 0.88 / \mathrm{lb}$ or $\$ 1,949 /$ metric ton; tin $\$ 3.13 / \mathrm{lb}$ or $\$ 6,909$ / metric ton; rare-earth oxides, $\$ 2.78 / \mathrm{kg}$ or $\$ 2,782 /$ metric ton. Based on these prices, the total gross in-place value of the undiscovered metallic resources in the quadrangle is estimated to be 1.4 billion dollars. Such an estimate does not imply that these resources would be economic to produce. Such a determination would require a complete analysis of the costs of discovering the deposits, engineering feasibility studies of mining and concentrating the ores, and an economic evaluation of metal production (White and others, 1989). The estimated gross-in-place value does provide however a measure of the total mineral resource 
value that can be compared with values estimated for other proposed land-uses by federal, state, and local government agencies if these values are also calculated on an in-place basis. 
Table 4. Estimated metal by deposit type within tracts in undiscovered mineral resources in the Livengood quadrangle (in metric tons)

\begin{tabular}{|c|c|c|c|c|c|c|c|}
\hline Tract & Deposit type & & Endow & ment val & ues $^{*}$ & & \\
\hline & Metal & 0.9 & 0.5 & 0.1 & 0.05 & 0.01 & Mean \\
\hline \multirow[t]{10}{*}{1} & Plutonic porphyry Au (20d.1) & & & & & & \\
\hline & $\begin{array}{c}\text { Au } \\
\text { Low-sulfide Au-quartz veins }\end{array}$ & 0 & 0 & 110 & 140 & 210 & 32 \\
\hline & (36a) & 0 & 0 & 70 & 31 & 130 & 63 \\
\hline & $\mathrm{Ag}$ & 0 & 0 & 0 & 0.2 & 10 & 0.83 \\
\hline & Polymetallic veins $(22 \mathrm{c})$ & & & & & & \\
\hline & $\mathrm{Au}$ & 0 & 0 & 0.1 & 0.4 & 6.3 & 0.21 \\
\hline & $\mathrm{Ag}$ & 0 & 1.5 & 84 & 240 & 1,800 & 72 \\
\hline & $\mathrm{Cu}$ & 0 & 0 & 29 & 110 & 1,500 & 72 \\
\hline & $\mathrm{Pb}$ & 0 & 180 & 11,000 & 30,000 & 88,000 & 5,600 \\
\hline & $\mathrm{Zn}$ & 0 & 8.1 & 4,600 & 16,000 & 100,000 & 3,900 \\
\hline \multirow[t]{4}{*}{2} & Porphyry-Mo low-F (21b) & & & & & & \\
\hline & Mo & 0 & 0 & 0 & 22,000 & 320,000 & 11,000 \\
\hline & Plutonic porphyry Au (20d. $\left.1^{\star \star}\right)$ & & & & & & \\
\hline & $\mathrm{Au}$ & 0 & 0 & 130 & 160 & 260 & 36 \\
\hline $3 a$ & Placer Au (39a)Au & 0 & 0.36 & 1.2 & 1.6 & 3.1 & 0.54 \\
\hline $3 b$ & Placer Au (39a)Au & 0 & 0.23 & 0.9 & 1.3 & 2.8 & 0.4 \\
\hline $3 c$ & Placer Au (39a)Au & 0 & 0.23 & 0.92 & 1.3 & 2.7 & 0.4 \\
\hline \multirow[t]{5}{*}{$4 a$} & $\begin{array}{l}\text { Low-sulfide Au-quartz veins } \\
\text { (36a) }\end{array}$ & & & & & & \\
\hline & $\mathrm{Au}$ & 0 & 1 & 34 & 76 & 190 & 13 \\
\hline & $\mathrm{Ag}$ & 0 & 0 & 0.4 & 2.9 & 72 & 2.1 \\
\hline & Simple Sb (27d) & & & & & & \\
\hline & $\mathrm{Sb}$ & 3.7 & 160 & 5,200 & 11,000 & 24,000 & 1,700 \\
\hline \multirow[t]{3}{*}{$4 b$} & Low-sulfide Au-quartz veins & & & & & & \\
\hline & $\mathrm{Au}$ & 0 & 0.4 & 19 & 60 & 170 & 10 \\
\hline & $\mathrm{Ag}$ & 0 & 0 & 0.01 & 1.1 & 30 & 1.6 \\
\hline \multirow[t]{10}{*}{5} & Porphyry-Mo low-F (21b) & & & & & & \\
\hline & Mo & 0 & 0 & 0 & 0 & 100,000 & 4,200 \\
\hline & Polymetallic veins (22c) & & & & & & \\
\hline & $\mathrm{Au}$ & 0 & 0 & 0 & 0 & 1.9 & 0.08 \\
\hline & $\mathrm{Ag}$ & 0 & 0 & 15 & 63 & 340 & 21 \\
\hline & $\mathrm{Cu}$ & 0 & 0 & 1.9 & 21 & 450 & 48 \\
\hline & $\mathrm{Pb}$ & 0 & 0 & 1,900 & 8,000 & 51,000 & 2,100 \\
\hline & $\mathrm{Zn}$ & 0 & 0 & 610 & 3,800 & 42,000 & 1,600 \\
\hline & Simple Sb (27d) & & & & & & \\
\hline & $\mathrm{Sb}$ & 1.3 & 78 & 2,700 & 8,000 & 20,000 & 1,200 \\
\hline \multirow[t]{2}{*}{6} & Sn greisen $(15 \mathrm{c})$ & & & & & & \\
\hline & Sn & 0 & 0 & 0 & 6,400 & 99,000 & 3,000 \\
\hline \multirow[t]{3}{*}{7} & Thorium-rare-earth (11c) & & & & & & \\
\hline & ThO2 & 0 & 0 & 2,000 & 6,000 & 46,000 & 2,100 \\
\hline & $\mathrm{ReO}$ & 0 & 0 & 0 & 96 & 59,000 & 3,900 \\
\hline
\end{tabular}

* Values rounded to 2 significant digits

** Grade and tonnage data from Fort Knox deposit, Alaska and Moksrko deposit, Czechoslovakia 
Bliss, J.D., and Cox, D.P., 1986, Grade and tonnage model of polymetallic veins, in Cox, D.P., and Singer, D.A., eds., Mineral deposit models: U.S.

Geological Survey Bulletin 1693, p. 125-129.

Bliss, J.D., and Orris, G.J., 1986, Descriptive model of simple Sb deposits, in Cox, D.P., and Singer, D.A., eds., Mineral deposit models: U.S. Geological Survey Bulletin 1693, p. 183-184.

Blum, J.D., 1982, Petrology, geochemistry and isotope geochronolgy of the Gilmore dome and Pedro dome plutons, Fairbanks mining district: Unpub. M.S. thesis, Univ. Alaska, 107 p.

Bottge, R.G., 1986, Availability of land for mineral exploration and development in North-Central Alaska, 1985: U.S. Bureau of Mines Special Publication, $37 \mathrm{p}$.

Bundtzen, T.K., 1983, Bedrock geologic outcrop map of the Livengood B-3 quadrangle, Alaska: Alaska Division of Geological and Geophysical Surveys Report of Investigations 83-6, scale 1:63,360.

Burton, P.J., 1981, Radioactive mineral occurrences, Mt. Prindle area, Yukon-Tanana Uplands, Alaska: Fairbanks, Alaska, University of Alaska, M.S. thesis, $72 \mathrm{p}$.

Cady, J.W., and Weber, F.R., 1983, Aeromagnetic map and interpretation of magnetic and gravity data, Circle quadrangle, Alaska: U.S. Geological Survey Open-File Report 83-170-C, scale 1:250,000.

Cathrall, J., Antweiler, J., Mosier, E., Tripp, R., and Lueck, L., 1985, Progress report on U.S. Geological Survey Alaskan gold project, in Madonna, ed., Proceedings of the Seventh Annual Conference on Alaskan Placer Mining, March 28, 1985: Alaskan Prospectors Publishing, Fairbanks, Alaska, p. 42-47.

Cathrall, J.B., Antweiler,, J.C., and Mosier, E.L., 1987, Occurrence of platinum in gold samples from the Tolovana and Rampart mining districts, Livengood quadrangle, Alaska: U.S. Geological Survey Open-File Report 87-330, 10 p.

Cathrall, J.B., Antweiler, J.C., Van Trump, G., and Mosier, E.L., 1989, Gold analytical results and gold signatures from the Fairbanks and Livengood quadrangles: U.S. Geological Survey Open-File Report 89-490, 32 p.

Chapman, R.M., and Foster, R.L., 1969, Lode mines and prospects in the Fairbanks district, Alaska: U.S. Geological Survey Professional Paper $625-\mathrm{D}, 25 \mathrm{p}$.

Chapman, R.M., and Weber, F.R., 1972, Geochemical analyses of bedrock and stream-sediment samples from the Livengood quadrangle, Alaska: U.S. Geological Survey Open-File Report 72-067, 2 sheets, scale 1:250,000.

Cobb, E.H., 1972, Metallic mineral deposits of the Livengood quadrangle, Alaska: U.S. Geological Survey Miscellaneous Field Studies Map MF-413, 2 sheets. 1974, Nickel occurrences in Alaska: U.S. Geological Survey Mineral Investigations Resources Map MR-63, scale 1:2,500,000. 1975, Chromite occurrences in Alaska: U.S. Geological Survey Mineral Investigations Resources Map MR-68, scale 1:2,500,000. 
1976, Summary of references to mineral occurrences (other than mineral fuels and construction materials) in the Livengood quadrangle, Alaska: U.S. Geological Survey Open-File Report 76-819, 241 p.

Collier, A.J., 1903, The coal resources of the Yukon, Alaska: U.S. Geological Survey Bulletin 218, $71 \mathrm{p}$.

Cox, D.P., 1986, Descriptive model of polymetallic veins, in Cox, D.P., and Singer, D.A., eds., Mineral deposit models: U.S. Geological Survey Bulletin 1693, p. 125-126.

Cox, D.P., and Singer, D.A., eds., 1986, Mineral deposit models: U.S. Geological Survey Bulletin 1693, 379 p.

Drew, L.J., Bliss, J.D., Bowen, R.W., Bridges, N.J., Cox, D.P., DeYoung, Jr., J.C., Houghton, J.C., Ludington, S., Menzie, W.D., Page, N.J., Root, D.H., and Singer, D.A., 1986, Quantitative Estimation of Undiscovered Mineral Resources--A Case Study of U.S. Forest Service Wilderness Tracts in the Pacific Mountain System: Economic Geology, v. 81, pp 80-88.

Fechner, S.A., 1988, Bureau of Mines placer investigation and mining feasibility study of the White Mountains Area, Alaska, in Madonna, J.A., ed., Proceedings of the Tenth Annual Conference on Alaskan Placer Mining: Fairbanks, Alaska, Alaskan Prospectors Publishing, p. 81-84.

Fechner, S.A. and Balen, M.D., 1988, Results of 1987 Bureau of Mines placer investigations of the White Mountains Study Area, Alaska: U.S. Bureau of Mines Open-File Report 5-88, 158 p.

Foster, R.L., 1968, Potential for lode deposits in the Livengood gold placer district east-central Alaska: U.S. Geological Survey Circular 590, 18 p.

Foster, R.L., 1969, Nickeliferous serpentinite near Beaver Creek, east-central Alaska: U.S. Geological Survey Circular 615, p. 2-4.

Foster, H.L., and Keith, T.E.C., 1974, Ultramafic rocks of the Eagle quadrangle, east-central Alaska: U.S. Geological Survey Journal of Research, v. 2, n. 6, p. 667-669.

Hargreaves, D., 1975, The Livengood placer deposit--A developing Alaskan gold mine: Mining Magazine, v. 132, p. 363-372.

Herbert, C.F., 1991, Livengood--Last of the Alaskan gold rushes, in Hollister, V.F., ed., Porphyry copper, molybdenum, and gold deposits, volcanogenic deposits (massive sulfides), and deposits in layered rock: Case Histories of Mineral Discoveries Volume 3, Society for Mining, Metallurgy, and Exploration, Inc., Littleton, Colorado, p. 235.

Hite, D.M., and Nakayama, E.M., 1980, Present and potential petroleum basins of Alaska, in Landwehr, M.L., ed., New ideas, new methods, new developments: Exploration and economics of the petroleum industry, v. 18 , p. 511-560.

Hollister, V.F., 1991a, Origin of placer gold in the Fairbanks, Alaska, area: A newly proposed lode source: Economic Geology, v. 86. n. 2, p. 402-405. 1991b, Fort Knox porphyry gold deposit, Fairbanks, Alaska, in Hollister, V.F., ed., 1991, Porphyry copper, molybdenum, and gold 
Robinson, M.S., Smith, T.E., and Metz, P.A., 1990, Bedrock geology of the Fairbanks mining district: State of Alaska Division of Geological and Geophysical Surveys Professional Report 109, 2 sheets.

Root, D.H., Menzie, W.D. II, and Scott, W.A., 1992, Computer simulation in quantitative resource estimation: Nonrenewable Resources, v. 1, p. 125-137.

Sangster, D.F., 1984, Felsic intrusion-associated silver-lead-zinc veins, in Eckstrand, O.R., ed., Geological Survey of Canada Economic Geology Report 36, p. 66.

Sherman, G.E., 1983, Geology and mineralization of the Silver Fox mine, Fairbanks mining district, Alaska: State of Alaska Division of Geological and Geophysical Surveys Report of Investigation 83-9, $56 \mathrm{p}$.

Sherman, G.E., 1987, Estimation of remaining lode gold endowments in selected mining districts of Alaska: U.S. Bureau of Mines Information Circular 1987, $26 \mathrm{p}$.

Singer, D.A., 1993, Basic concepts of three-part quantitative assessments of undiscovered mineral resources: Nonrenewable Resources, v. 2., n. 2, p. 69-81.

Singer, D.A., and Ovenshine, A.T., 1979, Assessing metallic resources in Alaska: American Scientist, v. 67, p. 582-589.

Staatz, M.H., 1992, Descriptive model of thorium-rare-earth veins, in Bliss, J.D., ed., Developments in mineral deposit modeling: U.S. Geological Survey Bulletin 2004, p. 13-15.

Swainbank, R.C., Bundtzen, T.K., and Wood, J., 1991, Alaska's Mineral Industry 1990: Division of Geological \& Geophysical Surveys Special Report 45, Anchorage, Alaska, 78 p.

Theodore, T.G., 1986, Descriptive model of porphyry Mo, Low-F, in Cox, D.P., and Singer, D.A., eds., 1986, Mineral deposit models: U.S. Geological Survey Bulletin 1693, p. 120-121.

Tripp, R.B., 1988, Distribution of selected minerals in the heavy-mineral fraction of stream-sediment, in Weber, F.R., McCammon, R.B., Rinehart, C.D., Light, T.D., and Wheeler, K.L., eds., 1988, Geology and mineral resources of the White Mountains National Recreation Area, east-central Alaska: U.S. Geological Survey Open-File Report 88-284, 120 p.

Tripp, R.B., in press, Distribution of selected minerals in the heavy-mineral fraction of stream-sediment, Livengood Quadrangle, Alaska: U.S. Geological Survey Open-File Report 92-

U.S. Department of the Interior Bureau of Mines, 1993, Mineral Commodity Summaries 1992, Washington, D.C., 201 p.

Wahrhaftig, C., 1965, Physiographic divisions of Alaska: U.S. Geological Survey Professional Paper 482, 52 p.

Weber, F.R., McCammon, R.B., Rinehart, C.D., Light, T.D., and Wheeler, K.L., eds., 1988, Geology and mineral resources of the White Mountains 
National Recreation Area, east-central Alaska: U.S. Geological Survey Open-File Report 88-284, 120 p.

White, B.A., Gunther, T.M., Johnson, R., and Adams, R.L., 1989, The potential supply of minerals from the White Mountains National Recreation Area and part of the North Steese National Conservation Area, Alaska: U.S. Bureau of Mines Open-File Report 12-89, 355 p.

Yeend, W.E., 1986, Descriptive model of Placer Au-PGE, in Cox, D.P., and Singer, D.A., 1986, Mineral deposit models: U.S. Geological Survey Bulletin 1693, p. 261. 